\title{
IMPACT OF MULTIPLE IMMIGRATION EXPERIENCE IN CHILDHOOD ON ETHNIC SELF-IDENTITY: \\ CASE STUDY OF RUSSIAN-SPEAKING ISRAELI CANADIANS
}

by

Natalia Markman, BA, Seneca College, 2015

\author{
A Major Research Paper \\ presented to Ryerson University \\ in partial fulfillment of the requirements for the degree of \\ Master of Arts \\ in the Program of \\ Immigration and Settlement Studies
}

Toronto, Ontario, Canada, 2016

(CNatalia Markman 2016 


\section{AUTHOR'S DECLARATION FOR ELECTRONIC SUBMISSION OF A MAJOR RESEARCH PAPER (MRP)}

I hereby declare that I am the sole author of this Major Research Paper. This is a true copy of the $\mathrm{MRP}$, including any required final revisions, as accepted by my examiners.

I authorize Ryerson University to lend this MRP to other institutions or individuals for the purpose of scholarly research.

I further authorize Ryerson University to reproduce this MRP by photocopying or by other means, in total or in part, at the request of other institutions or individuals for the purpose of scholarly research.

I understand that my MRP may be made electronically available to the public.

Natalia Markman 
Impact of Multiple Immigration Experiences in Childhood on Ethnic Self-Identity: Case Study of Russian-Speaking Israeli Canadians

\author{
Natalia Markman \\ Master of Arts 2016 \\ Immigration and Settlement Studies \\ Ryerson University
}

\begin{abstract}
This study analyzed the impact of multiple immigration experiences in childhood on ethnic self-identity of a group of immigrants who were born in Former Soviet Union states, who immigrated to Israel in childhood and immigrated to Canada as teenagers. The research question was: "What is the ethnic self-identity of Russian-speaking Canadian immigrants born in FSU countries who also lived in Israel and what contributes to it? Qualitative interviews with 8 participants were conducted and analyzed. Results showed that the majority of participants have mixed identities (often with strong connection to their FSU country of origin) developed due to the factors such as their immigration experiences, influence of their family, peer-groups and both negative (i.e. bullying) and positive experiences within the neighborhoods in which they resided. Few participants chose a single ethnic identity. Length of time residing in Israel seemed to matter in whether Israeli was part of their identity.

Key Words: Ethnic self-identity, Immigrants from Former Soviet Union Countries (FSU), Multiple Immigration Experience or Two-Step Immigration, Immigrant or Immigration Experience, Hybrid Ethnic Identity. Israel
\end{abstract}




\section{Acknowledgements}

I wish to thank all the individuals who contributed to this study. First and foremost, I'm thankful to my research supervisor Patrizia Albanese, $\mathrm{PhD}$, for her ongoing support, help and encouragement along the way. Her commitment to my research helped me to complete this study and report. I also would like to thank Mehrunnisa Ahmad Ali for being my second reader and reviewing my final report and giving feedback. I would especially like to thank all of my participants who kindly took time out of their schedules to be interviewed for this study. Without them this research would not be possible. Further thanks to Ryerson University and Yeates School of Graduate Studies for providing strong education and opportunities to complete this MRP. Thanks to all the dedicated individuals in the Research Ethics Board, for their time and consideration of my research proposal. I'm very grateful to all the faculty members of Immigration and Settlement Studies program who have taught me this past year and contributed to my research study. Finally, I would like to thank my parents, brother, my fiancé and my friends who believed in me and supported me through all years of my post-secondary education. 


\section{Table of Contents}

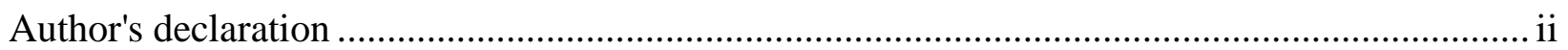

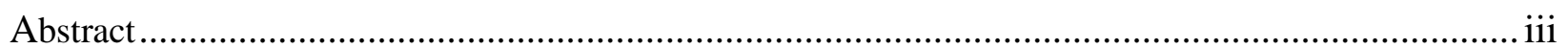

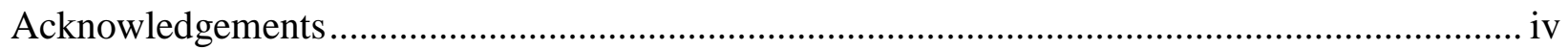

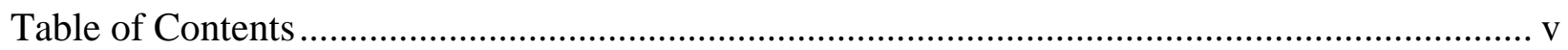

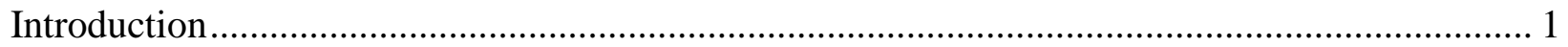

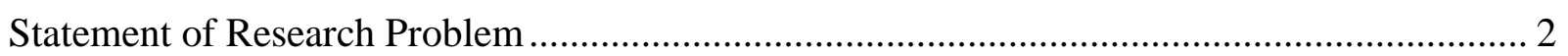

Ethnic Identity development of immigrant children ...................................................... 2

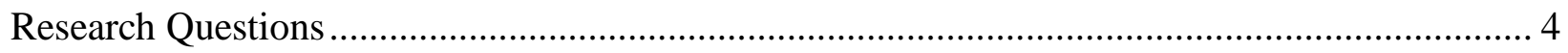

Justification of the importance of the problem ……….................................................................. 4

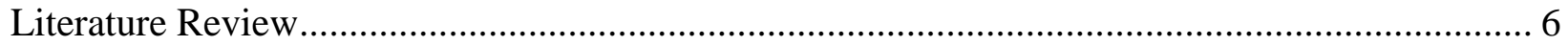

Theorizing adolescent ethnic identity formation among immigrant youth................................... 17

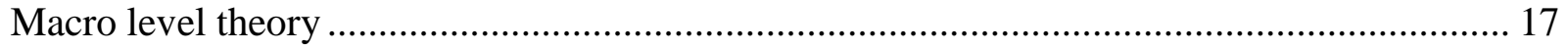

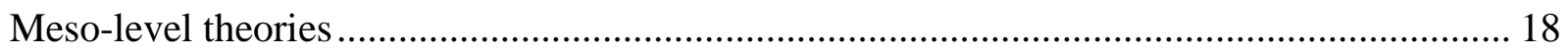

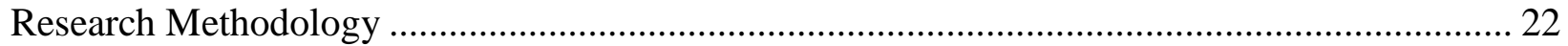

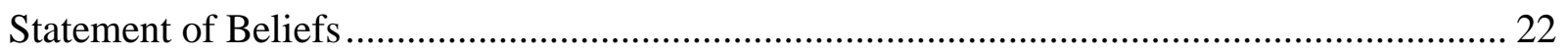

Philosophical assumptions and Paradigm ......................................................................... 24

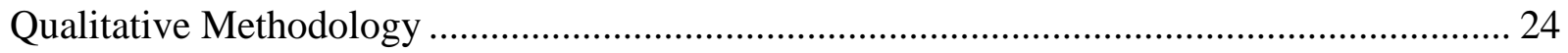

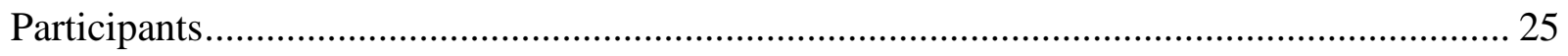

Outline of Participants Gathered:.................................................................................... 25

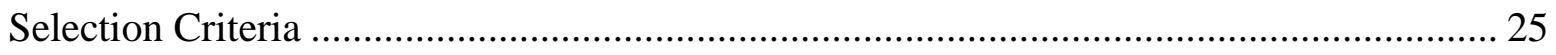

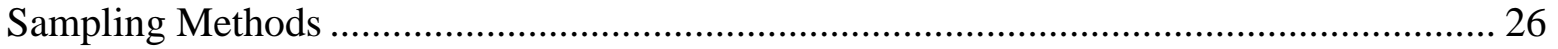

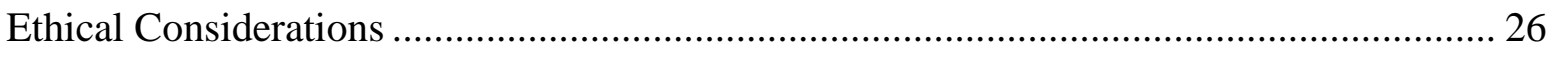

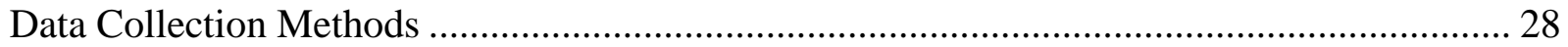

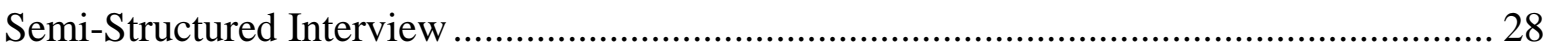

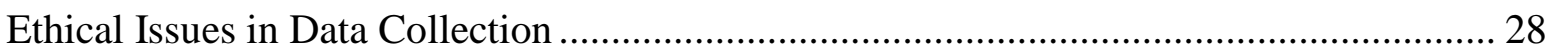

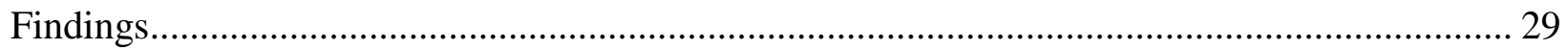

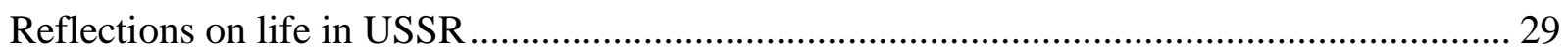

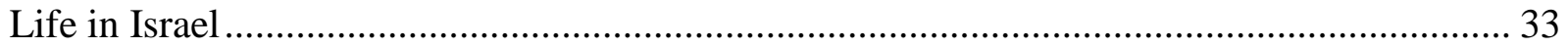




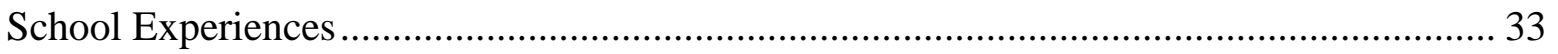

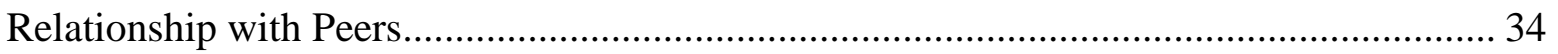

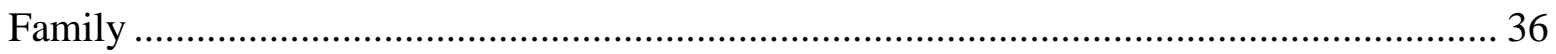

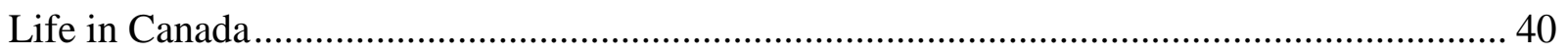

Peer Groups of Choice Today ......................................................................................... 40

Passing on traditions to future generation........................................................................... 41

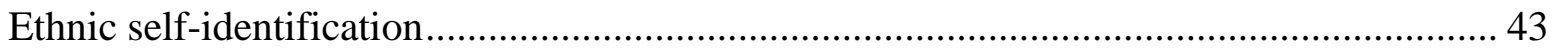

How particular ethnic self-identity chosen, helped or complicated participants' integration into

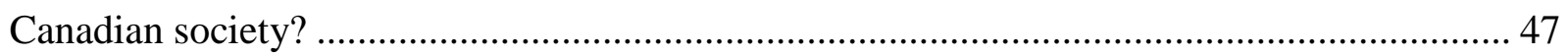

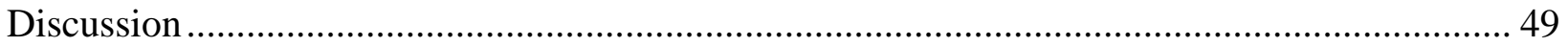

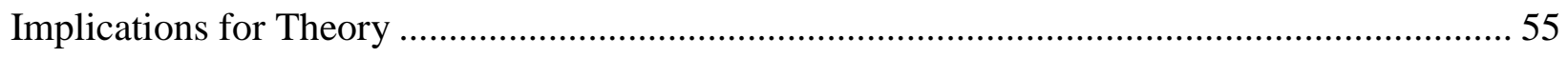

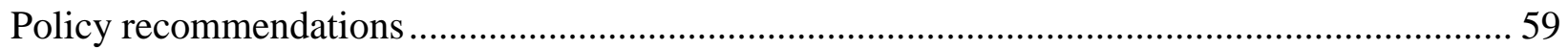

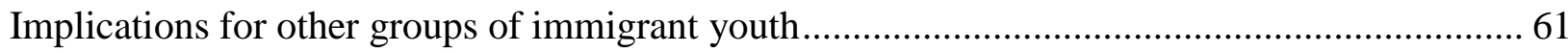

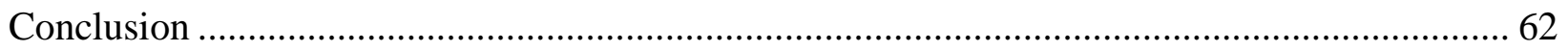

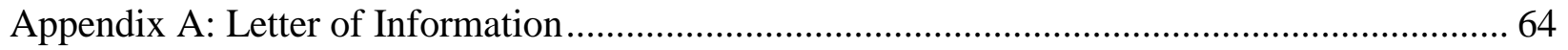

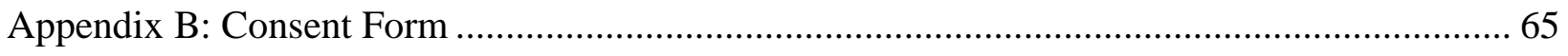

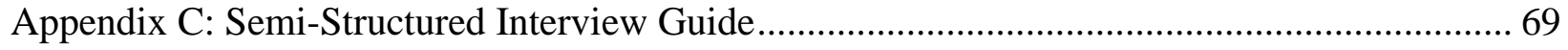

Appendix D: Recruitment post for Facebook community groups ................................................. 71

Appendix E: Research Ethnics Board Approval.................................................................... 72

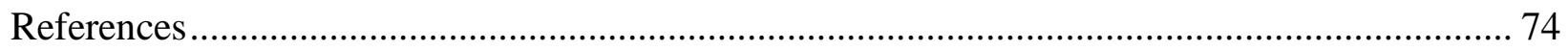

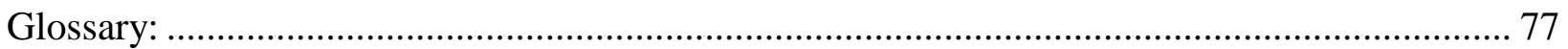

\section{List of Appendices}

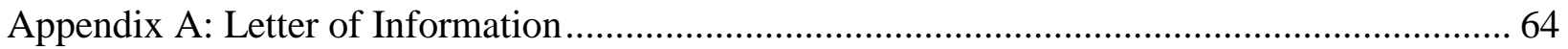

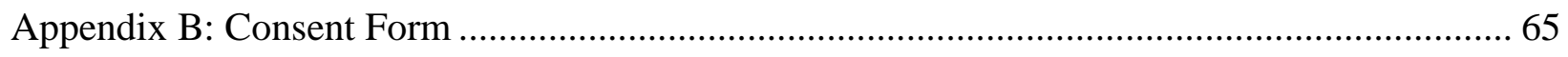

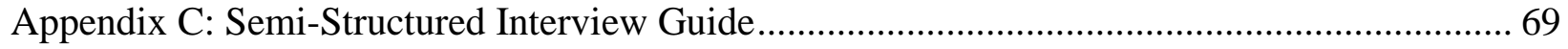

Appendix D: Recruitment post for Facebook community groups ................................................ 71

Appendix E: Research Ethnics Board Approval....................................................................... 72 


\section{Introduction}

A small-scale qualitative study was conducted in order to identify the impact that multiple immigration experiences in childhood have on ethnic self-identity of a particular group of Canadian immigrants; people who were born in Former Soviet Union Countries (FSU) and who lived in Israel as a result of their first immigration in childhood. The present study used semi structured interviews to determine the ethnic self-identification of participants and their immigration experiences. The aim of this study was to understand the formation of ethnic identity in adolescence and the factors that might have had the most impact on the unfolding of particular identity developed to this current point of the participants' lives. The following paper provides an overview of the research problem, theoretical framework, a literature review of studies previously conducted in the field, a description of the data collection through the interview process, data analysis and interpretation of the main findings related to the research questions as well as discussion of the study, limitations and suggestions for future research. This

research study is qualitative, based on the individual experiences and personal feelings of each individual participant. It is a small scale study, with only 8 people interviewed within the Greater Toronto Area (GTA). While the study cannot offer conclusive nor generalizable results, it presents some interesting findings that provide support for previous research and can be used to inform future studies. 


\section{Statement of Research Problem}

\section{Ethnic Identity development of immigrant children}

A common and popular area of research in the field of immigration and settlement in recent years has been the topic of identity of immigrant children (Trabka, 2013; Birman et al, 2010; Glozman, 2015; Phinney et al., 2000). It is particularly important to understand ethnicself-identity during the end of the $20^{\text {th }}$ and beginning of the $21^{\text {st }}$ century, when human mobility is so common and many are living transnational lives, i.e. live in one country, but are deeply involved in social, cultural and political life of their country of origin through media and other forms of communication (Remennick, 2006). National borders are getting more permeable with modern technology and easy mobility. At the age of this global migrant movement where some people can immigrate one or more times though their life span, it is very interesting to research what are the identities of immigrants today. Do people who migrate prefer to identify with a single ethnic identity (if so, which one?) or do they develop a hybrid ethnic identity that mirrors their life experiences through immigration (Harper et al., 2013)? What are the factors influencing self-identity formation?

While most adults usually make the decision to migrate, children typically follow their parents/guardians to a new country (for exceptions, see Ali, Taraban and Gill, 2003). Adults who come to a new country often have an already established ethnic-identity that they have developed while growing up in their country of origin. According to multiple theories, identity development accelerates in adolescence (Erickson 1968, Marcia 1966, Pinney 1996), therefore immigrant children are in the midst of developing their identities when or after they move. They experience change in their social environment, language, and culture, and this inevitably plays a role in their identity formation (Birman et al., 2010; Allen \& Aber, 2006; Zubida et al., 2013; Trabka, 2013). 
There is a very limited number of studies done in Canada on Russian-speaking immigrants. This group has a unique set of experiences, closely connected to the relatively recent history of Soviet Union collapse. This historical event contributed to formations of new independent countries with their own national languages, values and prides (such as Ukraine, Belarus, Latvia etc.) which in turn might have created multidimensional ethnic identities. For many, identification with FSU is unpleasant as it was often connected with the "occupation" of their state in the past. Civil war in Ukraine is perhaps the best example of this (for more on this, see Kappeler, 2014). Children of those who were born and raised in USSR, likely now have complex identities because they are raised in a new era but at the same time were closely connected with the common values of FSU. Children who then immigrated to Israel and Canada, might have even more unique experiences that could add to the multiple dimensions of their identity formation (Glozman, 2015).

Glozman (2015) referred to the Russian-speaking immigrant group in Canada as an "invisible" community "whose invisible nature may impact their identity and sense of belonging following their arrival in Canada" (p.2). This author made an assumption that this particular group of immigrants may not easily integrate with mainstream white Canadians but at the same time may not fit with other visible minority groups (Glozman, 2015, p.2).

My study builds on Glozman's observation and aims to help generate new knowledge about ethnic self-identity of immigrants from (FSU), particularly among those who re-migrated from Israel, and who now live in Canada. It is important to find out how these immigrants define themselves in terms of ethnic-identity in order to better understand their integration patterns into Canadian society and well as identify unique challenges experienced by this particular group. 


\section{Research Questions}

The key question that I researched through my study is: What is the ethnic self-identity of Russian-speaking Canadian immigrants born in FSU countries, and who also lived in Israel?

Two additional questions provided fuller and more meaningful information on the factors that lead to specific ethnic-identity of my participants: What are the main factors that contributed to their ethnic self-identity? How does this particular ethnic self-identity help or complicate their integration into Canadian society?

Like Birman et al. (2010), I think that ethnic-identities of immigrants from FSU counties with two-step immigration experience through Israel will be complex and multidimensional. Like Umaña-Taylor et al., (2006) and Phinney et al., (2000), I think that immediate family has a very strong impact on a child's ethnic identity formation, along with peer interactions. I think that negative experiences such as bullying related to ethnicity/culture through immigration can also have an impact of identity formation (Remennick \& Celnik, 2011).

I believe that childhood and adolescence experiences are the key contributors to this formation. These assumptions had been made based on my beliefs in social constructivism, the ecological model of child development and identity development theories, personal experiences, and a literature review that contains studies previously done on ethnic-identity formation.

\section{Justification of the importance of the problem}

Glozman (2015) stated that Russia is one of the top immigrant source countries in Canada since the collapse of Soviet Union. According to Statistics Canada (2011), about 11 percent of the population in Canada speaks Slavic languages such as Russian and Ukrainian. The National Household survey reported over 500,000 people of Russian origin living in Canada, more than a 
million Ukrainians, 15655 Belarusians, 27335 Latvians and 8050 Moldovans (Statistics Canada, 2006). These countries were formerly parts of Soviet Union and today are a significant source of Russian-speaking immigrants in Canada. The Russian-speaking Jewish community in the GTA has expanded from only a few thousands in the 1970s to approximately 60000 to 70 0000 today (Remennick, 2006). Approximately 70 percent of Russian-speaking Jewish immigrants reside in the GTA, and others settle in a few other immigrant-receiving cities such as Vancouver and Montreal (Remennick, 2006). Within this segment of immigrants there are two groups; one that comes straight from FSU countries and others who come as a result of remigration from Israel. Those who re-migrated from Israel make up 50 to 70 percent of all Russian speaking immigrants that came after 1990 (Remennick, 2006) and this is the group of focus in this study.

This research contributes to the limited body of literature on this particular immigrant group in Canada. The current study might be helpful for community and settlement organizations and other institutions such as schools that closely work with youth immigrant groups because results demonstrate factors that impact ethnic identity formation. Results also present challenges this particular group is facing because of their multiple immigration experiences. 


\section{Literature Review}

Ethnic identity of immigrants is a popular topic in research on immigration and settlement. In order to understand the meaning of ethnic identity, and its distinction from the notions of national and cultural identity, we turn to the research of those who explored these terms in some depth.

Birman, Persky and Chan (2010) have identified the difference between culture, nationality and ethnic identities. According to them, ethnic identity refers to "an individual's sense of self in terms of membership in their native culture or ethnic group" (Birman et al., 2010, p. 194). They contrasted that with national identity, which they argue "refers to the extent of identification with the country wherein the immigrants now reside" (Birman et al., 2010, p. 194). Their study explored the multiple identities of Jewish immigrant adolescence from FSU countries in USA. It focused on how Jewish adolescents integrate their Russian, Jewish and American identities and to what extend their identification "predicts their adaptation to varied life domains" (Birman et al., 2010, p. 193). A sample of Jewish adolescents was compared to a sample of non-Jewish youth.

The study found that ethnic identity of Jewish adolescence is complex because participants reported a variety of types of self-identification including Russian, Russian-American, Russian Jewish, Jewish American, Ukrainian Jew and many other combinations. These results demonstrated the complex nature of their identity. Participants struggled to construct their identity and had difficulty explaining it to other people (Birman et al., 2010).

Another finding was that Jewish adolescents were more likely to associate themselves with American identity than non-Jewish adolescents who participated in the study. Researchers 
attributed this outcome with the history of anti-Semitism in USSR that might have affected the higher level of "rejection" of Russian identity by Jewish families and therefore higher level of "willingness" to integrate into American society. A related finding was regarding the level of Russian identity by both groups. Jewish immigrant adolescents had lower levels of Russian identification compared to non-Jewish immigrant adolescents (Birman et al., 2010). The study also found that participants had very low religious involvement, leading the authors to make the prediction that it might be the reason why some ethnically Jewish adolescents did not have a strong connection with Jewish identity. Another explanation was that adolescents are still in the developmental stage of their identity and have yet to commit to a specific identify (Birman et al., 2010).

Another study that looked at the ethnic identity of immigrants was done by Sumetsky (2007). This author conducted a study of the identity of immigrant children from FSU in the United States. The purpose of this study was to understand identity of people who immigrated to USA in their childhood (before 12 years of age) from FSU countries that include Belarus, Ukraine, Uzbekistan, Kazakhstan, Latvia and 10 other countries. The author described and explained the "russification" process during Soviet Union era that "imposed the Russian language on non-Russian speaking groups and made other calculated attempts to draw each nationality's individual identity closer to one that would be coherent with the Russian" (Sumetsky, 2007, p. 1).

The key results of that study showed that American child immigrants from the former Soviet Union identify themselves less as Americans, and more with nationalities related to FSU countries (Sumetsky, 2007). The researcher did not find significant differences in ethnic identity based on the age of arrival of the participants, despite predicting that age might play a role 
(Sumetsky, 2007). American citizenship was found to be an important factor in ethnic selfidentification, meaning that participants who held citizenship were more likely to identify themselves as Americans. Also, participants who reported their (back-home) national and ethnic identities as important to them, were reporting lower levels of identification as Americans. The author concluded that participants who were raised in families who put strong emphasis on ethnic/cultural/national identification, carried it into adulthood and therefore were more connected to their roots (Sumetsky, 2007). That said, the author reported that the role of community remained unclear in this study. She suggested that the ethnic self-identity within the Russian speaking community would probably be more towards a "Russian" identity because it is more readily available (Sumetsky, 2007).

One of the few Canadian studies that focused on Russian Jewish immigrants was conducted by Remennick (2006). The author looked at the identity and social integration of Russian Jewish immigrants in Toronto from two subgroups: one group were Russian Jews who came straight from FSU and the other group were re-migrants that came through Israel (Remennick, 2006). Some of the key results were as follows.

In both groups, the reasons for coming to Canada were mostly similar--better economic opportunities. Re-migrants from Israel also had additional reasons such as Middle Eastern culture that was very different and uncomfortable to them in Israel and unsafe situations in the country because of ongoing military conflicts in the region and fear of military draft for children (Remennick, 2006).

The study also found that Russian Jewish immigrants in Toronto from both subgroups, had very little involvement in Canadian mainstream society (outside of school or work) as well as with the larger Jewish community. Although in their interviews they expressed satisfaction with 
the multicultural policies and practises in Canada and didn't ever feel that they were being discriminated against, they none-the-less tried to stay within their own community. One of the participants stated: “They (Canadians) seem to live on another planet. I don't think they could understand us (recent immigrants) even if they wanted to..." (Remennick, 2006, p. 70-71). This quote greatly represented the "trend" in this particular immigrant group.

When asked about their connections with the Jewish community, many participants expressed opinions that Canadian Jewish community is more religiously observant and they felt that it was also expected from them. One of the participants stated: "We are not Jewish enough for Canadian Jews" (Remennick, 2006, p. 71). In the introduction to the study the author provides reasons for this, including: "Most former Soviets raised in the atheist mindset rejected this culture (Jewish) as backward and incompatible with modern democracy" (Remennick, 2006, p. 64).

The study showed that families with non-Jewish spouses were the least to try to connect their children with their Jewish roots (celebrate holidays or send them to Jewish schools); families with two Jewish parents were more inclined to participate in Jewish life in Toronto. Similarly, Jewish immigrants who came from big cities such as Kiev, Moscow etc, were fully assimilated and did not express any interest in participating in Jewish community life in Toronto (Remennick, 2006). There were slight differences between the two subgroups on that matter: Russian Jews who came through Israel were more willing to participate in Jewish community life versus those who came straight from FSU. Connection was especially stronger for children who grew up in Israel (spoke fluent Hebrew, left friend there etc.).

Although the information about children and youth (so called 1.5 generation) was informal because information was gathered through interviews with parents, the author still managed to 
get some information about their adjustment to Canada. According to their parents' reports collected through interviews, children and youth adjustment was difficult due to cultural and linguistic gaps especially for these who came straight from FSU countries and did not experience another immigration. Those who came from Israel, were more "Westernized", had experience in a different school system, their English was better, and they were feeling more secure (Remennick, 2006). Interviewees reported their children to be more connected with Russianspeaking friends. "Russian immigrant youth display a whole range of social profiles, from high achievers who excelled in high school and entered universities to marginal and alienated youths hanging out in the streets" (Remennick, 2006, 76). Although the author didn't have direct information from youth, she pointed out that more parents reported troubled and less adjusted youth especially among those who came from FSU in comparison with those who came from Israel (Remennick, 2006).

All participants in this study reported having a transnational lifestyle. Russian culture and language, as well as Soviet Union past, makes Russian-speaking immigrants a unique and strongly connected community. Participants reported being highly involved and interested in political affairs and news from in their FSU country of origin through media, press and internet. There were strong connections reported with relatives and friends who stayed in Israel and FSU (for all ages) and many travel back home (FSU countries) to visits (Remennick, 2006). Overall, results showed that re-migrants from Israel were better equipped for life in Canada and better adjusted rather than counterparts who came straight from FSU (Remennick, 2006).

While Remennick, in her qualitative study, focused primarily on adult Russian speaking immigrants and gathered information from parents, Glozman (2015) conducted qualitative research specifically on Russian-speaking adolescent immigrants to Canada. This research 
included semi-structured interviews that provided insight into ethnic-identity of Russianspeaking youth. Among those, many re-migrants from Israel where interviewed. Results of this study revealed some interesting differences between identities of Russian-speaking Canadianborn, Israeli-born, and FSU-born youth. Israeli-born youth expressed mostly Russian and Jewish identity, despite the place of their actual birth or residence (Ukraine, for example). Canadianborn youth were more inclined towards their Jewish identity, and FSU-born participants, even those who re-migrated through Israel were more likely to identify with their or their parent's place of birth (Glozman, 2015). The author came to the conclusion that "identity is fluid and identity choice and expression may shift according to the situation" (Glozman, 2015, p. 152). Youth also reported that their multiple identities were beneficial to them especially the multilingual aspect (being able to speak multiple languages). Their overall response was that their ethnicity is accepted in Canada and they can be who they are (Glozman, 2015).

Another result of this study was around Jewish identity. Youth viewed "Jewish" more as a cultural rather than religious concept which supports the previous research that FSU immigrants are generally more secular and not religious. For those born in FSU, Christian Orthodox identity affiliation was strong despite the fact that most of them revealed that they are not religious and it was seen more as part of the culture in their families (Glozman, 2015).

Glozman (2015) also concluded that the majority of youth among all three groups did not identify themselves as Canadians first. "Youths reported valuing Canada and experiencing a sense of belonging in Canada, in part because Canada's multiculturalism policy allowed them to reside in ethnic enclaves and maintain their own cultures. Even among Canadian-born youths in the study, the Canadian identity was never ranked first (Glozman, 2015, p. 158). 
One more finding was around the factors mainly influencing identities of youth in this study. Glozman (2015) named parents as the most important factor of influence on identity formation among this group of youth. "Their direct influence was rooted in what they taught their children and shared with them within the home, whereas their indirect influence was through the choices they made about neighbourhoods, schools, and extracurricular activities for their children" (Glozman, 2015, p. 163). Other factors contributing to ethnic self-identify included peers and community, and especially living in ethnic enclaves (Glozman, 2015). This particular study inspired my own research, as it looks at similar topics and has a very similar research focus.

My current study, involved participants that went through immigration via Israel and therefore it is important to review research done on the "transfer point" of immigrants lives, in Israel. It is important to understand the challenges and nuances of life in Israel that could be potentially impacting ethnic identity of immigrant youth.

One of the studies that looked at Russian immigrant youth in Israel and their identification was an author that was already mentioned in this literature review. Remennick and Celnik (2011), conducted a qualitative study involving questionnaires, focus groups and in-depth interviews among 300 high school and middle school students. The main focus of the study was to understand identity dilemmas of children of Russian parents. The overall results of the study showed that 54 percent of all respondents chose identity related to their parents' country of origin, such as Russian and Ukraine. These results showed the retention of ethno-cultural identity by $2^{\text {nd }}$ generation immigrants to Israel (Remennick \& Celnik, 2011). "The tendency to identify as Russian was corollary to a higher Russian language proficiency and its more frequent usage outside of the home (i.e. with friends, teachers, etc.), Russian preferences in reading and media 
consumption, the predominance of co-ethnic friends, and positive attitudes towards both Russian high and everyday culture (e.g., expressed in politeness, self-restraint, respect for elders, and other such behaviors uncommon among young Israelis)" ( Remennick \& Celnik, 2011, p. 29). These results demonstrate the alienation of Russian immigrant youth in Israel from the mainstream culture.

Other interesting results showed that 37 percent of youth said their friends outside school are only Russian and only 11 percent responded that they have only Israeli friends. Others said they have a mixed friends circle. A large number of participants also responded that strongly agree that they keep in touch with family and friends from FSU (39\%), and 28 percent agreed, which demonstrates the importance of transnational ties (Remennick \& Celnik, 2011).

One of the unpleasant results of the study was that many participants reported cases of abuse and discrimination in school settings, from their native Israeli classmates. "While most respondents (about 80\%) described their current peer relations at school as peaceful, friendly or at least neutral, many of them had experienced severe episodes of exclusion and bullying by native Israeli peers in the past, mostly in elementary school" (Remennick \& Celnik, 2011, p. 3132). Acts of exclusion triggered reaction of isolation and alienation by bullied children, “compelling 'Russian' kids to lump together for self-protection and company” (Remennick \& Celnik, 2011, p. 32). These kinds of experiences might have a strong impact on developing identity of youth and might be one of the factors that contribute to "sticking" to people with similar backgrounds.

For the purpose of my study, I thought it useful to look at immigrant youth ethnic identity development done on other immigrant communities as well. It is important in order to 
understand some more "universal trends" compared to trends that are more unique to the FSU community.

A Canadian study by Schimmele and Wu (2015) explored ethnic identity of new immigrants to Canada. The authors synthesized main research studies and literature on acculturation and social identities of immigrants to Canada and USA after 1965 and their key findings showed that the first generation of immigrants prefers to choose their original ethnic identity while their children tend to develop a mixed-identity such as Chinese-Canadian (Schimmele \& Wu, 2015). Bicultural identities (for example Chinese-Canadian, JewishCanadian etc.) are very common among Canadian immigrants of second generation. The two explanations suggested by the authors are first, that multiculturalism policy in Canada encourages cultures of immigrants coming to country and supports retention of them in various ways. The second explanation was that "some racial minorities are hesitant to "drop the hephen" because of subtle perceptions of being less "Canadian" than their White counterparts" (Schimmele \& Wu, 2015, p. 3). Other findings were that the original self-identity is very important for both first and second generation of immigrants. Another interesting result was that discrimination discourages the sense of belonging to the new country, and as a result creates “politicized identities” (Schimmele \& Wu, 2015, p. 3).

One article by Trabka (2013) focused on identities of "third culture" children. She studied the influence of multiple immigration experiences in childhood on identity formation. This author used the term "chameleons" to refer to children who experience multiple immigrations and had to "adapt" to the new environments (Trabka, 2013). As part of her $\mathrm{PhD}$ dissertation in Krakow, Poland, Trabka interviewed 53 children whose parents were from Poland, USA, Germany, China, India, UK and Korea (Trabka, 2013). All interviewees were connected with at 
least two countries in their childhood. Most of interviewees (who were adults by the time she interviewed them) were skilled workers and economic migrants, raised by parents who were doctors, teachers, military, business etc. (Trabka, 2013). This study confirmed that the role of parents in the transitional period is very important because children have to be prepared for the immigration experience. Results showed that significant others such as family, close acquaintances, and friends are very important especially during the transitional period. Children need to be prepared for the immigration experience because it gives them sense of control over their life (Trabka, 2013). This study also showed that identity of many participants often had a fluid component and was "under construction" most of the time, but their "social environment however, forced them to identify themselves once and for all, to somehow relate to existing national and ethnic categories" (Trabka, 2013, p. 96). Participants of this study stated that connection with other children who went through similar experiences helped them to deal with the stress associated with adaptation and was most important in helping to build their own identity (Trabka, 2013).

Phinney, Romero, Nava and Huang (2000) similarly explored a variety of influences on ethnic self-identity formation of adolescents, including the role of language, parents and peers. These researchers surveyed adolescents and their parents from three immigrant groups: Armenian, Vietnamese and Mexican living in the USA. Immigrant adolescents completed tests and questionnaires with scales of ethnic language proficiency, their in-group peer social interaction and their ethnic identity. Parents completed a questionnaire with scales on their support for cultural maintenance of their children (Phinney et al., 2000). The results showed that “across all groups, ethnic language proficiency and in-group peer interaction predicted ethnic 
identity, and parental cultural maintenance predicted adolescent ethnic language proficiency" (Phinney et al., 2000, p. 135).

Other results of this study showed that across all groups, social interaction with peers of the same ethnic background was positively correlated to ethnic self-identification. Peer connections were found to be an even more powerful factor for ethnic identity formation, followed by ethnic language retention within the family. Socialization of parents and children and their input in maintaining the culture, are key factors that impact on ethnic language retention for children (Phinney et al., 2000).

A study by Umaña-Taylor, Bhanot and Shin (2006) explored ethnic identity formation and specifically the critical role of families in this process. A large sample of 639 adolescents from different communities was gathered. There were representatives of multiple communities including Chinese, Salvadorian, Filipino, Indian and Vietnamese. The main finding of the study was that socialization with the family plays a significant role in ethnic identity of all groups of adolescence from all communities represented (Umana-Taylor et al., 2006). "Regardless of the fact that the five groups examined in the current study have varying cultural traditions, values, beliefs, and histories in the United States, the familial context appears to be critical to all groups for adolescents' ethnic identity formation. Thus, this suggests that one commonality in the process of ethnic identity formation is the strong influence of families" (Umana-Taylor, 2006, p. 407).

The literature review done for the purpose of the current study explored the research topic from a variety of perspectives. Previous research done on immigrant youth from FSU's ethnic identity formation was presented along with research on other immigrant communities. The main findings of previous studies are used as a point of reference for results of my study. 


\section{Theorizing adolescent ethnic identity formation among immigrant youth}

\section{Macro level theory}

The philosophical assumptions that were guiding my research are based on a belief that identity is a complex structure which is based on an individual's experiences. I believe that each person has their own unique experiences that lead to a particular identity or hybrid identity. These philosophical assumptions have lead me to turn to a social constructivist paradigm. A pioneer of social constructivism, Lev Vygotsky theorized: "An interpersonal process is transformed into an intrapersonal one. Every function in the child's cultural development appears twice: first, on the social level, and later, on the individual level; first, between people (interpsychological), and then inside the child (intrapsychological)" (Vygotsky, 1930, p. 48). Vygotsky theorized that it applied to such functions as voluntary attention, child's logical memory and the concepts formation process. All these developing functions are rooted in the social relations between human beings (Vygotsky, 1930).

Choosing social constructivist approach to ethnic identity formation means to treat it as a learning process that unfolds through internal and external processes. At first, the child observes and absorbs information from other people around him/her, and in the process of growing and developing, they internalize these experiences and build concepts that cumulate their identity. Examples of this include language their parents and people around are speaking, traditions and celebrations specific to ethnic communities, food, music etc.

As a researcher, I expected that each interview with my participants will be a unique experience. That said, I also anticipated some similarities across experiences. Although I recruited people having similar immigration experiences in childhood and similar cultural 
background, I did hear (as was expected) some unique details during interviews that influenced them to choose the ethnic-identity they developed.

My study is based on a belief in the existence of multiple realities. The data collected through this study was based on a unique information provided by my participants that shared their own experiences and thoughts. For this and a number of other reasons, the results of my study cannot be considered universal, nor generalizable to larger populations.

\section{Meso-level theories}

There are other theories that have shaped my approach to understanding identity development. One is Urie Bronfenbrenner's Ecological Systems Theory:

"A broader approach to research in human development that focuses on the progressive accommodation, throughout the life span, between the growing human organism and the changing environments in which it actually lives and grows" (Bronfenbrenner, 1977, p. 513). In simple words, human development is affected by a child's surroundings that are also subject to change.

There are few levels of systems in the ecological theory that are closely connected and influence the child directly and indirectly. According to Bronfrenbrenner (1994), the first system is called microsystem and it is the immediate environment in which child grows and develops. This would include their families and peers and other people who are being in the everyday immediate surrounding of the child and have everyday interactions with him/her. The other layers of the system are: mesosystem, exosystem, macrosystem and chronosystem. According to Brofenbrenner (1994), each of these systems influence the child indirectly. The mesosystem includes linkages between immediate environments and the impact of that linkage on a child. 
For example family and school, parents and teachers:" In other words, a mesosystem is a system of microsystems" (Bronfenbrenner, 1994, p. 40). The exosystem includes/involves linkages between settings that might not influence the child directly but might affect people who interact with this child. For example parental workplace (Bronfenbrenner, 1994). The macrosystem includes cultural and social ideologies in the place where the child lives: "It is a societal blueprint for a particular culture or subculture" (Bronfenbrenner, 1994, p. 40). Finally, the chronosystem looks at the historical conditions in which child is living (Bronfenbrenner, 1994). Bronfenbrenner believed that children's environments are not static and influence each person in different ways. My views support this theory because every person lives in and experiences different conditions. By applying this theory to my study, I make an assumption that even if historical period and place of residence are the same, all children have different factors and life circumstances that influence them and their ethnic-identity formation directly and indirectly.

Another theory that can inform ethnic-identity formation is Erik Erickson's theory of identity formation. I believe that this theory contains important theoretical assumptions that can shed light on ethnic identity formation. Erik Erickson was one of the first scholars who recognized the concept of identity as one of the important personality achievements in adolescence (Erickson, 1968). In his book Identity, Youth and Crisis (1968), Erickson defines identity as follows:

"In psychological terms, identity formation employs a process of simultaneous reflection and observation, a process taking place on all levels of mental functioning, by which the individual judges himself in the light of what he perceives to be the way in which others judge him in comparison to themselves and to a typology significant to them; while he judges their way of judging him in the light of how he perceives himself in comparison to them, and to types that 
have become relevant to him" ( Erickson, 1968, p. 22-23). His theory of identity formation focuses on the psychological struggle that the adolescent is going through in order to attain specific self-identity (Erickson, 1968). Drawing on Erickson's work, other scholars state that "forming a healthy, developed identity through the process of exploration and commitment was proposed as essential to the mental health of an individual" (French, Seidman, Allen \& Aber, 2006, p. 1).

Inspired by Erickson's work on identity formation, Phinney developed a theory of Ethnic Identity Formation which is the central theory for this current study. Phinney (1996) explains ethnic identity as: "Ethnic identity has been conceptualized as a complex construct including a commitment and sense of belonging to one's ethnic group, positive evaluation of the group, interest in and knowledge about the group, and involvement in activities and traditions of the group" (p. 145). He believed that ethnic identity is flexible and can change over time depending on the context and that there are many factors that are influencing ethnic identity development, such as family, society, community, peers etc. (Phinney, 1996). According to theory of Ethnic Identity, there are 3 stages that a person goes through while developing an identity. The first stage is Unexamined Ethnic Identity, at this stage an adolescent simply accepts identity, values and attitudes "provided" to him/her by his/her immediate environment and puts little thought into it. The relationship with his/her ethnic group might be positive or negative or neutral, depending on the overall attitudes and the child's socialization within the child's environments. The relationship to other ethnic groups can also be different depending on the "examples" given by child's family and other authoritative figures (Phinney, 1996).

The second stage is called Moratorium or Exploration, at this stage the adolescent starts to actively explore his/her identity. "As adolescents move into a larger world, encounter more 
people from backgrounds different from their own, and are increasingly exposed to discrimination. These experiences trigger the desire to understand the history, traditions and current situation of their group" (Phinney, 1996, p. 146). That means that at this stage according to Phinney (1996) adolescents are very ethnocentric and focused on their own group that they feel most comfortable in.

The third stage is called Achieved Ethnic Identity. A person develops some type of ethnic identity and feels secure. At this point, ethnicity might not anymore be salient to them and they are open to other groups in society. "Those who see the possibility of minority and majority groups working together to achieve common social goals support integration and favor working towards positive intergroup relations. However, those who are disillusioned with the status quo and see little possibility for change may believe that minorities are better off becoming selfsufficient within their own communities and thus embrace a philosophy of separatism" (Phinney, 1996, p. 147). Although this particular ethnic identity theory is directed towards racialized populations, I find it very applicable to my research. When taking into consideration the fact that Russian-speaking immigrants are "minorities" in Israel, adolescents can also be going through a similar path of ethnic identity development, with similar results. Considering the fact that Jews were subject to repression throughout history and even extermination during WWII by Nazis, the feeling of being "minority" still lives and thrives. In modern times, being Russian in Israel is also a difficult experience, as I demonstrated through the literature review above. Taking into consideration all these factors, I will be taking Theory of Ethnic Identity by Phinney as a main theoretical framework for my study. 


\section{Research Methodology}

\section{Statement of Beliefs}

I decided to conduct this study because of my personal experiences in childhood which are directly related to the experiences of the participant group and to the research problem of ethnicidentity formation.

I was born just before the collapse of Soviet Union in 1990 and left Russia for Israel at the age of nine. My mother is of Slavic Russian origin and my father is a Russian Jew. My father's ethnicity gave us an opportunity to immigrate to Israel. My father is an atheist and never practiced Judaism or any other religion. My mother baptized me and my brother in the Russian Orthodox Church and it was one of the factors that I think contributed to my ethnic self-identity as a Russian. While living in Israel and attending primary and middle school, I experienced a lot of discrimination from peers based on my "Russian appearance" in clothing, heavy accent, the food I was eating, and overall "otherness" from Israeli stereotypical behaviors and customs. This led me to develop friendship bonds with other Russian-speaking immigrants, which I believe contributed further in my not identifying with other Israelis. Not surprising, according to Erickson's theory of identity development, adolescence is an important time for identity development (Erickson, 1968). I spent six years in Israel, from the age of nine until the age of sixteen, which means that in this period of time I was developing my identity and constructed ethnic understanding of myself. After finishing secondary school I asked my parents to send me to the only high-school in Israel with prevalent Russian-speaking contingent. I commuted a few hours every day to get to this school (located in another city) just to be surrounded by people of the same language and culture. This school was more based on the "Russian" educational system (more emphasis on mathematics and sciences in the earlier grades, compared with other Israeli 
schools); it also had Russian-speaking teachers and staff. I was able to take Russian literature classes and feel myself "connected" to my country of origin. All these components created an "illusion" of continuity of Russian culture for me in Israel. No doubt this experience significantly influenced my further ethnic self-identification.

Another factor that I consider important is that we speak only Russian at home and my parents encouraged me to read books in Russian, watch movies with Russian audio tracks, celebrate Russian holidays (such as New Year's), cook Russian food etc. Even after sixteen years since our immigration from Russia, I continue to be up-to-date with Russian news, pop-culture and even am politically involved (I voted in Russian presidential elections at the Russian consulate in Toronto).

My second immigration, to Canada, was very difficult for me, particularly because of the "unknown" environment and the fact that I left my comfort zone. I didn't know if I would be able to find a similar social environment in Canada. After arrival, I consciously started looking for Russian-speaking friends as part of my social safety-net in a new place of residence. Even today I continue to associate primarily with members of my original ethnic identity, and would answer "Russian" to the question of my ethnic identification.

I did not expect to get the same answer from participants but was interested to hear from people who went through the same path in terms of their immigration experience, to see how they identify themselves and what were the factors and social contexts behind their identification. I think it is important to present a standpoint that I come from as a researcher as it directly influences my study and helps shed light on my subject position. 


\section{Philosophical assumptions and Paradigm}

I have selected a qualitative methodological approach for my study as I believe it most accurately reflects the epistemological, ontological and axiological assumptions I hold and therefore aligns well with the social constructivist research paradigm. As I have chosen to conduct a qualitative study, my results present the unique as well as shared circumstances in which participants live, the meanings that they attribute to their experiences and the pathways to their ethnic self-identification. Phinney (1996) suggested that qualitative method of interviewing participants is the best to study ethnic identity of participants as it gives the most in-depth information on participants. Qualitative studies allow for "emerging questions and procedures, data analysis inductively building from particular to general themes, and the researcher making interpretations of the meaning of the data" (Creswell, 2014, p. 4). This approach gave more valuable information because of the "open-ended" nature and flexibility in data collection, as my strategy for data collection is semi-structured interviews. This method allowed conducting more open-ended interviews and asking additional questions that emerged as a result of information given by interviewee.

\section{Qualitative Methodology}

I selected a qualitative approach and specifically semi-structured interviews as my strategy in order to collect the results that I thought would better represent ethnic self-identification of my participants and factors that influenced it. I believe this approach and strategy helped me to gain in-depth understanding of the factors and unique circumstances that contributed to identity development in a particular group of participants. Semi-structured, face-to-face interviews allowed me to study my research interest through the eyes of the people being studied. Glozman's (2015) dissertation that inspired this current study, also used qualitative methods of 
data gathering in her research about identity of Russian-speaking immigrants and came up with a very in-depth results. Like Glozman (2015), I conducted semi-structured interviews that provided me with very detailed and unique information about every participant and helped me to find common themes and draw meaningful conclusions. Remennick and Celnik (2011), Trabka (2013) and Remennick (2006), also used qualitative approaches in their studies. Their findings are points of comparison for the results of my study.

\section{Participants}

\section{Outline of Participants Gathered:}

Recruited participants included adults above the age of 18 who were born in FSU countries (Russia, Ukraine, Belarus, Latvia etc.), immigrated to and lived in Israel, and then immigrated to Canada before or at the age of 18. All participants were recruited from the Greater Toronto Area. The sample size included a total of 8 participants: 3 female and 5 male participants. The sample is small compared to other studies mentioned above due to time limits given for this MRP.

Non-random, non-probability sampling was used for this research study. Participants who had the specified immigrant experience and who were above the age of 18 were selected for the study. As a result, I used purposeful/purposive sampling, followed by some snowball sampling when participants referred me to other people who had similar experiences and were interested in participating in this study.

\section{Selection Criteria}

Participants had to be above 18 years of age. They had to be born in Former Soviet Union countries. Participants should have passed through the adolescent stage of their development that according to Erickson (1968) and Phinney (1996) is the main point of time when ethnic identity develops. I was looking for participants who are young adults and likely developed some type of 
achieved ethnic identity (Phinney, 1996). They should have gone through a two-step immigration to Canada through Israel as it is the main research criteria on this study.

Participants should have both of their immigration experiences before or at the age of 18 . Participants were recruited only in the GTA to ensure possibility of face-to-face interview. Only applicable candidates who fit the research criteria above were interviewed for this study. They were also first generation immigrants to Canada, meaning they came to Canada, either with their parents or by themselves. Participants were recruited under the knowledge that they would have to spent at least 30 minutes on the interview and under written agreement that they would be audio-recorded.

\section{Sampling Methods}

Two types of sampling methods were used in the process of participant's recruitment. The first was purposive/purposeful sampling. Purposeful sampling was used to target very specific population in social media groups were the chance to target them are higher. The second type of sampling was snowball sampling, already recruited participants referred other people with similar experiences. Glozman (2015) also used snowball sampling, explaining that "snowball sampling strategy was employed due to the inherent difficulty of recruiting this immigrant population and to capture the experiences of youths who may not use community services and programs" (p. 78). Recruiting through social media, as I originally planned, proved to be difficult, and not effective, when targeting this population.

\section{Ethical Considerations}

Each participant read and signed a consent form, and voluntarily agreed to have the interview audio-recorded (See Appendices A and B for Letter of Information and Consent Form). Facebook online community groups were used to recruit participants. A Facebook post 
was created for Toronto Russian and Jewish community groups with the details of the research study and call for participation. I provided my Ryerson email to minimize personal risks and asked not to comment under the posting to maintain confidentiality of those who might have been interested in participating.

I assured participants of the confidentiality of their personal information. I also informed participants of how their interviews will be used in my study. All their personal information (such as real names, contact information etc.) was removed from the research documents and wasn't used for any purposes. Names were replaced by pseudonyms.

Another ethical issue that I considered was related to the interview questions. I reviewed them with my research supervisor to make sure they would not cause discomfort for my participants.

One more ethical issue that I anticipated was the willingness of participants to withdraw from my study. The information letter ensured them that they had the option to withdraw without penalty and/or explanation at any point in the process of my study. This statement was intended to increased their comfort level and not make them feel pressured in any way to participate. I also committed to destroy any data including interview notes and audio-recording within 24 hours in case of any participant's withdrawal. The last consideration was the storing of information. I committed to securely storing all personal information of my participants and documents related to my study.

During the interview process, none of the participants dropped out of the study, all of them answered all the questions and didn't raise any of the ethical concerns that I prepared for. 


\section{Data Collection Methods}

\section{Semi-Structured Interview}

Face-to-face, semi-structured interviews were used as the singular tool of data collection. A basic interview guide was formulated with twenty open-ended questions directly related to the research questions. In the process of each interview, more questions were added as a response to some of the participant's comments that lead to more in-depth analysis of each story (see Appendix D for interview guide). Researchers that took a similar approach to ethnic identity research (Remennick \& Celnik, 2011; Trabka, 2013; Remennick, 2006: Glozman, 2015) used indepth, semi-structured interviews. I chose semi-structured to have more flexibility in my conversations with participants and to be able to ask more questions in response to their answers, to clarify information and make usage of the unexpected information that came out during interviews.

Interviews were held in the Ryerson Library study rooms that were booked in advance for each interview. Each interview was done one-on-one with participant to ensure confidentiality of the information and their identification.

\section{Ethical Issues in Data Collection}

One of the ethical considerations was the clarification of any definitions that I was using during interview to make sure my participants understood them the same way as I did. Another consideration was the level of comfort to answer the questions. I ensured them that they can skip any question that they don't feel comfortable to answer. None of these ethical issues came up during interview process. I also reflected on my own biases to minimize subjectivity in |my research. 


\section{Findings}

Present study included a total sample of 8 participants: 5 males and 3 females. All of them were born in the Former Soviet Union States: 4 participants were from Ukraine, 2 from Russian Federation, 1 from Latvia and 1 from Belarus. All participants spent some of their childhood and adolescent years in Israel before coming to Canada. This findings section is divided into three themes: (1) Reflections on life in FSU country based on participants' childhood memories and parental stories; (2) life in Israel as children; and (3) adolescence and life in Canada as young adults. Seven out of 9 participants reported one of their parents being of Slavic (Russian, Ukrainian, Belarusian) background and the other parent with Jewish roots (meaning both or one of the grandparents was Jewish). One of the participants reported his father was Armenian and Greek with his mother's side was Jewish. This connection to Jewish roots gave each family the opportunity to immigrate to Israel.

\section{Reflections on life in USSR}

All participants left FSU countries in their early childhood. Age of arrival to Israel varied for all participants; starting from 9 months old to 7 years old. Only one participant went to grade 1 in Ukraine before he left for Israel. Some of the memories that participants recalled about their life in FSU countries were related to family lifestyle and traditions. John ${ }^{1}$ (age 27) recalls:

Well, we had the regular celebrations that go on in Ukraine. We are from Crimea which is a Russian speaking part of Ukraine, so it was mostly Russian traditions: New Years, birthdays, things like that. So we weren't really religious at all pretty much... No we didn't celebrate Jewish holidays at all.

\footnotetext{
${ }^{1}$ All names have been changed to protect participants' identities.
} 
A similar answer was given by Vivian (age 27), who responded that her family only celebrated New Years and birthdays, and mentioned that she was baptized in Ukraine. Kate (age 27) as well stated that her family did not practice any Jewish traditions within the family. Paul (age 23) stated that his family traditions are mostly Christian:

We were baptized as kids. Mom kind of did it for us. My dad is not really religious, I mean, he would celebrate Jewish holidays but he was not religious, he never had a problem with Christians or anything like that. I wouldn't say we are a religious family. We just celebrate the main holidays. And in Israel we would respect their holidays and we would celebrate it just like any other person.

John (age 27) also recalled that he was baptized in Ukraine:

I do remember that I was baptized but I think parents only told us that we're Jewish kind of close to the time that we decided to immigrate. So it was never a part of our life and we never kind of celebrated any Jewish holidays or any traditions or anything like that. We did not know anything about Israel or anything. That was a Christian neighbourhood that we've been in and Simferopol is obviously a Christian city and so they baptized us to fit in I guess... Like everybody else does.

Only Rick (age 26) reported that his mother really wanted to connect to her Jewish roots and that was the reason his family immigrated to Israel:

From the little that I do know, I know that my mother was really, really, really, really pushing for it, she wanted to connect to her Jewish roots, and immigrate to Israel, especially after the fall of the USSR. 
None of the participants reported any Jewish traditions or family cultural practices while living in FSU countries, when I asked them a question about it. All of them left FSU in 1990's, soon after the fall of USSR. All interviewees were asked about the main reasons that made their family move to Israel. Some of the motives were healthcare, financial and the safety situation after the collapse of USSR. Two people talked about anti-Semitic behaviors towards their family:

Kate (age 27): They even burned our cottage down because we were Jews.

Another person tried to explain the connection between anti-Semitic attitudes and the immigration process to Israel, from a bigger perspective:

We left in 1995, shortly after the Soviet Union collapse...so basically if people where leaving there was this kind of sentiment that you're kind of like a traitor, not per say but you're turning your back on your homeland and you're going elsewhere... So it was kind of harder part of the reason we were able to leave to Israel was because of antiSemitic reasons. That was also part of the reason why we were accepted to Israel (John, age 27).

John (age 27) also recalled:

The main decision was family wellbeing... So Ukraine obviously had limits in what it could offer...basic things such as you know...nutritional food, the absence of it, sometimes we would lose electricity you know... The things that you would expect in Western society to provide weren't provided there. Parents left to search for better life. They figured that we would have a lot more opportunities outside of Ukraine and when there was opportunity to move to Israel they started to do the research and find out how 
great it is, they decided to move just for our wellbeing. That was the main reason pretty much.

Melany (age 24) and Paul (age 23) named financial reasons and more opportunities as the main motivation to immigration from FSU country, while Michael (age 30), Jeff (age 28), Vivian (age 27) and Kate (age 27) reported safety reasons such as organized crime in 1990's as the main motives for their families.

Michael (age 30) recalls:

In Ukraine there was a lot of gangsters in the area where we lived and there was a lot of crime, organized crime. And my dad saw a person got hit by a car and the people just drove away. And also my dad knew from his dad, who was a general, and he knew some of the bad people that were in that area and he didn't want to stay there for that reason. It was just being overtaken by crime and organized crime.

Healthcare also was one of the concerns named by John (age 27), Michael (age 30) and Jeff (age 28). Michael (age 30) remembered that many people were getting Cholera (epidemic disease). Jeff (age 28) stated that his grandmother had breast cancer and his family was looking for better healthcare opportunities for her.

None of them recalled any memories about their ethnic identity back in FSU countries due to the fact that they were too young at the time of their first immigration. Although that question appeared in all interviews, this sample did not involve people who were old enough to remember experiences that made them think about their specific identity directly. 


\section{Life in Israel}

For all participants, life in Israel was a period of their late childhood and early adolescence. All of them went through school experiences and adaptation to a new culture, language and environment. In this section, the memories about their life in Israel are presented through three main filters: school experiences, relationship with peers and family.

\section{School Experiences}

There was a lot of similarities in the participants' school experiences in Israel. Some of them recalled being "pushed" towards mainstream society in their school environment.

John (age 27) recalls:

Actually, there was that sort of sentiment of "if you're going to be here, we're speaking Hebrew and you should be following Jewish traditions and things like that and then there was some negative feedback that we received because of our origin. Basically the idea was that you have to integrate into Jewish society. Things outside of that were kind of frown upon... I wouldn't say there was any kind of hatred or threat or violence or anything like that but definitely felt some kind of negative vibe.

The same person mentioned that in regular public school he didn't feel too much pressure about teaching newcomers Jewish traditions and culture. He said that some general knowledge was provided through mandatory afterschool programs for newcomers:

Sometimes during the year, they asked some students to stay after school, after regular scheduled classes to learn some Jewish traditions and stuff. So kind of what you would learn in Jewish school, but they had really condensed version of it; to stay an hour after school is over and they would teach some stuff. But that was pretty much the only 
kind of Jewish education that we were receiving in that school because it wasn't a religious school. We didn't have requirements to wear kipa or anything like that.

Melany (age 24) went to religious school in Israel because it was the closest one in their neighborhood and had negative memories of it:

I had to go to Orthodox religious school in grade one and a little bit of grade two but I really didn't like it. I remember I was crying to my mom because they made us read the Torah and I didn't understand it. And we had to always pray and I didn't want to do it because it wasn't what my family at home would do, like we're not following the Jewish religion actually at all, so I had to basically follow everything all the time. Then my mom realized that it wasn't the right place for me so in grade two she moved me to nonOrthodox school.

All 8 interviewees stated that due to very high numbers of immigrants from USSR countries that immigrated to Israel in 1990's and early 2000's, every school had a large number of Russianspeaking children. Also, all of them reported that they were living in immigrant populated neighborhoods with a large Russian-speaking population. Some mentioned that their parents also made only Russian-speaking friends and other connections while in Israel.

\section{Relationship with Peers}

A lot of similarities came up through interviews when they talked about their peer connections in Israel. One of the most interesting findings was the fact that every single participant recalled incidents of being bullied by their "native" Israeli peers and the feeling of alienation between Russian-speaking and "native" groups. Few people directly attributed this to them choosing Russian-speaking friends as their safe haven and group of choice for everyday communication at some point in their childhood. Participants explained that the main reason for 
bullying by Israeli natives was the study participants' "otherness" and their "Russian" background. Few of them remember being called bad names such as "Rusi Masriah" ("Disgusting Russian" in Hebrew), or "Russian Pig". All remembered being picked on because of their appearance, accent and the food that they were bringing to school (not kosher). Vivian (age 27) summarized this in a powerful quote and admission that she still feels strong negative emotions when remembering the bullying incidents in her childhood:

I remember I was the Russian kid; like, we were so Russian. I think only the past few years the Russians are... Like everyone understands that everyone that comes from Russia they actually Jewish, and it's okay to be Russian and Jewish at the same time. But back then it was, me and my sister we were Russian and yeah we had kids bullying and it's still in my heart, it's still! I remember those people, they on my Facebook and I remember what they done and it was, it was kind of hard, a little bit.

Kate (age 27), also shared very powerful words to express the bullying:

You know kids, hear "Russians go back to Russia", the kids pick up on that and obviously they do hear their parents saying, they'll go and say to like another child at school which was me... So that was probably the main negative experiences that I remember.

A few interviewees talked about their "first friend" in Israel, who was always a Russian-speaking child. Michael (age 30) shared that the teacher consciously asked the boy to show him around and so then they became friends. Melany (24) who came to Israel at a very young age (9 months old) said that although she grew up in Israel, she still felt more connected to her Russianspeaking peers. 
Melany (age 24):

I formed those Russian speaking friends, maybe because I felt connected with them and like because we spoke Russian...Even when I was going to my ballet classes my best girlfriend was Russian too, we would get very close with her. And a lot of my actually family members, their kids were Russian, so I was with them. And then, I don't know how we formed this Russian group, you know, people that spoke only Russian, but it just happened and I ended up being in this group.

Paul (age 23), explained the desire to connect with Russian speaking peers in Israel by stating:

You always try to stick with your own kind. As far as you can. Plus, they were friends even though... That's not true actually, I did have a few close friends who were actually Israeli, after a while. I think after several years, maybe, of living there. And we were really good friends. For the first several, maybe two or three years, most or pretty much everybody of my friends were Russian speaking.

Everyone said that they had a Russian-speaking group of friends in Israel. Some mentioned that they had some native Israeli friends but most participants reported that their main group of friends was Russian-speaking. Bullying incidents were mainly remembered in connection with primary and middle school years. Almost everybody stated that the situation improved towards their adolescent years and while they were in high school. Many mentioned that they made good friend with native Israeli peers later in life, and to this day have Hebrew-speaking friends, both from Israel and here in Canada.

\section{Family}

While answering questions about their family during their life in Israel, participants 
mentioned many hardships that their parents were going thought during the adjustment process. Many remembered that their parents struggled to find suitable employment, had difficulties with learning the language and with immersing themselves in Israeli culture. Almost everyone said that their parents stayed within the Russian-speaking community. Few of them particularly noted that at least one of their parents disliked Israeli life and only saw it as a transfer point, before a second immigration.

Michael (age 30) stated:

They were never planning to stay in Israel. They just kind of used Israel as a stopover. They didn't have enough money I think to get to Canada and Israel did not need capital cost, you know, per head.

The same person told me that the family was saving on everything including a TV, car etc. in order to save money and leave.

Kate (age 27), also spoke about one of her parent's dissatisfaction with life in Israel:

My step-dad hated it. He wasn't Jewish, right. So he really didn't like it, he couldn't like, he refused to speak, he actually forbidden us to speak Hebrew at home. Which was kind of stupid because this way if we spoke in Hebrew at home they could have picked up the language and that never happened for them, right, it never worked out for them. But anyways, he hated it, so that's why we moved to Canada. It was his initiative.

Paul (age 23) remembered a very frightful turning point in his parents' perspective on life in Israel: 
They weren't sure. My mom definitely didn't want to stay in Israel. My dad was okay with it until terrorism started and it was always around us, it just never... They got in to a situation where it happened pretty much right in front of their eyes and that was sort of the point where they truly decided "Yeah, we have to get out of here. This is not a place we want to stay and live in.

Similar reasons were mentioned by almost all participants, including terrorism, unstable safety situation, cultural differences, lack of stable employment and army service in the near future of their children.

Another commonality among participants was the maintenance of their first language, at home, following their first immigration. Many talked about the fact that in their families, parents continued to speak Russian with their children while leaving in Israel (and later in Canada). This was in fact mentioned as a priority among their parents. A few of them mentioned that some Hebrew words were used as well but Russian stayed the first language in each family. Some stated that parents were very strict about the use of their first language at home and maintained this through both immigrations.

Melany (age 24), revealed an interesting fact by remembering that she became interested in learning to read and write in Russian. She mentioned that this was her choice and not something that her parents pushed her to do. She asked her grandmother to teach her. Melany came to Israel the youngest of all 8 interviewees. She was 9 months old upon her first immigration.

I had always lot of family members fly from Russia or from Belarus to visit us, like all the time. And when I was five my grandma she moved from Belarus to Israel and she lived first with us. I remember my cousin, she was two years older than me and I was 
always so jealous that she came from Russia to visit and she would read all these Russian books and she would know such sophisticated Russian and she always told me, "Your Russian's not so good", so I wanted to prove to everybody that I can also know Russian. I told my grandma, "teach me!", so she got me those azbuka it's called and those books to practice how to write cursive Russian and in general I knew all the alphabet. And then, yeah, I started reading and writing in Russian, when I was eight basically.

She also disclosed that sometimes her peers for wanting to learn Russian but it didn't stop her from continuing the process.

Kate (age 27) also mentioned that her grandmother used to read her Russian fairytales:

I used to love when my grandma would read Russian skazki, like Russian fairytales. Yes, I loved it. So, it was just a combination. Inside the house it was Russia, outside the house it was Israel.

Rick (age 26), also said that his parents not only maintained Russian language at home but also ensured that their child continues to pursue a more "Russian" education:

My parents wanted me to improve on different areas where they think I was lacking so they found all kinds of programs, people who were off to school, programs that were run by immigrants from USSR as well so have very high level programs for math and English and so forth and so forth, so you get a few years jump on the current curriculum in your school, and most of those people were Russian speaking.

Overall, participants revealed that all 8 of their families had similarities in their pattern of first immigration and reasons to leave Israel for Canada. Two of them who spent the longest time in Israel (Rick (age 26) and Kate (age 27)), who left at age 17 and 18 were the ones who miss their 
life there the most and were the ones who talked about the diversity of friends they had in the later years in Israel and the emotional difficulty of their second immigration. Rick (age 26) called Israel his home, although he was born in Russia and the decision to immigrate to Canada was his own.

\section{Life in Canada}

This section of findings about the participants' life in Canada is divided into three parts: (1) participants' peer groups at this current point of their lives; (2) their plans and desires about passing on family traditions to their children; and finally, (3) results on my main research question, about their self-identification with a specific identity.

\section{Peer Groups of Choice Today}

All 8 participants reported that the main peer groups and their closest friends at this moment in time are Russian-speaking from FSU countries. Only Vivian (age 27), specified that most of her friends are Ukrainians but all of them speak Russian in addition to Ukrainian.

Some participants also mentioned that they have a few friends from other backgrounds; Vietnamese (Melany (age 24) and Paul (age 23)), Canadians (Participants John (age 27), Michael (age 30), Melany (age 24) and Paul (age 23)). French-Canadian and Indian (Melany (age 24)). Some participants specified the background of their friends by saying Russian-Israeli (Melany (age 24), Rick (age 26) and Kate (age 27)) or Russian-Jewish (Michael (age 30)).

One of the most interesting responses about their peer group of choice as a young adult in Canada was given by Rick (age 26): 
I think that's one of the best combinations of Israelis is that blend of the Russian and Israeli with that easy going joking mentality of being Israeli with understanding of some I guess behaviors and calls of respect, contact, understanding of environment that the Russian aspect can bring.

Kate (age 27) gave a very similar explanation about the mentality of Russian-Israelis:

More formal approach which is Russians, right like cold. But I would still have the Israeli chutzpa a bit. You know what I mean? So I think it's the best mixture of both because you can be very formal and respectful, I guess, when you need it, and you can be more easy going when you need that part of you. Because, the Israel, the actual Israel, those who were born and grew up in Israel, you can spot them from a mile away. Like they don't have this composure, they just, "Ah!"...Loud!

\section{Passing on traditions to future generation}

Another question that was asked during the interview was focused on the desire of participants to pass on their language, traditions and culture to their children as a future generation. Answers revealed that most participants considered it important to pass on their language/traditions/culture to their future children and they would do specific steps towards achieving this goals in their families.

All eight participants said that they would want their children to speak Russian. Rick (age 26) said that Hebrew is more important to him, but he would still want his children to learn Russian as well. Melany (age 24) and Paul (age 23) said that they would want their children to go to Russian-speaking kindergarten and classes later in life in order to give them some type of "Russian" education. Michael (age 30) and Jeff (age 28) want their children to be fully assimilated into Canadian culture, but speak or at least understand Russian. Vivian (age 27) 
wants her children to live in Israel at least at some point in their childhood. Five participants said they would take their children back to their FSU countries of origin to show where they came from. Michael (age 30) (the only participant that already has a son) took his son to Israel but that that he wouldn't take him back to Ukraine. Five participants said that they would want to take their children back to Israel to visit and show them where they lived. Two participants (John (age 27) and Melany (age 24)) said they would not pass on religion, others didn't mention religion in their answers.

Only one participant, who has son, was able to answer this question by reflecting on his experience as a parent.

Michael (age 30):

I remember when I had already married and moved in to my house that I bought on my own and I had a wife and a child, and had my parents over I said something English to my mom and my dad freaked out and yelled, "Speak Russian in the house!" and I said, "This is my house and in my house we can speak whatever language we want." So that it got, it irritated him to that level that he shoved it down our throats "Speak Russian in the house!", even though he has no authority in my house he's still telling me to do it. So that kind of built up some hard, bad feelings about this whole topic in that I don't like to be told to do that. The approach I take with my son is very different, instead of forcing him I remind him that, "Let's speak some Russian because your grandparents speak Russian and it's good to know that language." He's a smart kid, he automatically you know, "I understand", he wants to, he understands the benefit. So it's not, you know, I don't want him to do one or the other. He will do the easiest and you know the easiest is to do nothing. So if I let that happen he'll forget Russian and that's not something that I want. But I don't 
want him to be Russian, I don't want him to feel Russian. He's not going to be feeling that no matter what I want. But to remember the language and to try to practice, that's something I always do with him.

\section{Ethnic self-identification}

The main research question posed in this study, brought very interesting results through the interview process. I decided to include some of the most powerful quotes related to the question of ethnic self-identification for each participant to demonstrate the thought process behind each answer. Five participants disclosed mixed identities to include two components: Russian-Israeli, Russian-Jewish, Russian-Ukrainian and Ukrainian-Jewish. Four participants named mixed types of identities with Russian as being the main component and the other related to either religion (Jewish), or other country (Israel, Ukraine).

Participants that disclosed Russian-Israeli Identity:

Melany (age 24):

I always thought Russian-Israeli. So where do I identify myself? So basically in Israel I was feeling proud to be Israeli, not so much Russian. And then when I came to Canada I became more proud to be both of them; Russian-Israeli, half and half.

Kate (age 27):

Russian-Israeli. It's a specific type of culture or whatever you want to call it. Yeah, Russian-Israeli. Because in Israel I couldn't get along with the - not that I was fighting with them - I just couldn't find a common language with the few Russians who just refused to belong to Israel and just spoke only Russian, it just wasn't my thing.

Participant that disclosed Russian-Jewish Identity: 
Michael (age 30):

Russian-Jewish, yeah. Or maybe Russian... I think I'm more Russian culture than Jewish culture. But I wouldn't call myself purely Russian, I'd say I'm Russian-Jewish.

Participant that disclosed Russian-Ukrainian identity:

John (age 27):

I definitely align myself more with being Russian than being Jewish, but because of my experience in Ukraine and Israel were so short timewise, and even though we did assimilate for the time being, while we were in Ukraine and in Israel...I spent in Canada far longer time than either of those countries...Canadian values are a lot alike with Ukrainian values and some of the traditions and even holidays... I mean the major once. I would consider myself Canadian but if I was to kind of say which I feel more like Russian, Ukrainian or Jewish... I would say Russian-Ukrainian but overall definitely Canadian.

Only one participant called herself Ukrainian-Jewish but disclosed that when people ask she sometimes says Russian because it is less confusing to others.

Vivian (age 27):

It's mixed, well I think mixed. Yes of course it's mixed. We were baptized when, in Ukraine and I still go to church sometimes, but I'm still Jewish. And it's hard for me, it's hard to explain people that there's religion and then there's culture... It's hard to explain, like I'm in the middle, like really I, I don't know who I am. Really it's hard, it's hard when it's all mixed. I'm saying that I'm Ukrainian-Jewish, honestly, yeah. No I'm, no. I'm confused only now. Because now as a grown person I'm, I know where I'm coming from. 
In Israel I was the Ukrainian kid, not even Ukrainian I was Russian, which was hard to explain, "no I'm from Ukraine", but I think that's what I'd been called, that I'm Russian. At first I felt Israeli, I was acting very Israeli - loud and, but now I think I'm more Russian, I guess, I don't know, it's really something... Yeah it's something really, really deep and I like, I don't even know. The brain understands that I'm a pre-war Israeli kid but the heart I'm still Ukrainian. It's funny that I don't remember anything from Ukraine, but that's the way it is.

Only one participant called himself Russian:

Paul (age 23):

I feel like I would say Russian, than anything else. I just feel like it comes from the family, how they act. If the family gets adapted to the country quickly, than you as a person would feel the same way. But our family was always Russian speaking, would always speak Russian at home, would celebrate New Year's and other holidays that are celebrated in Russia, and it was always, and sporting events anywhere where Russia would show up we would always cheer them on, that would be our first priority for any event. And pretty much I would feel like first thing's first I would be Russian. I never thought about it. I always know, I know and I always knew that it didn't matter which country you were at, you still feel like a Russian, at least my family does, that's what my family made me feel.

Only one participant said that he feels himself Canadian but with some Russian mixture:

Jeff (age 28): 
First of all, I'm very confused because I was born in Soviet Union, which then became Ukraine and then I lived in Israel and then I live in Canada and now my part of Ukraine joined Russia, so, who am I? But I feel Canadian. With some Russian mixed in, but not much Jewish mixed in. So I don't, I don't follow Judaism.

Only one called himself Israeli:

Rick (age 26):

Israeli. I think it's just, it's not your blood, it's not your parents, it's not necessarily the people you hang around with. It's what you feel like you belong to. It's what culture you feel like if you go to environment of this culture you're immersed in, what do you feel that you belong to, what do you feel that this is home, where do you feel that you connect to the most? It doesn't matter how long you lived in a certain place, a certain environment, hoping to attach to a certain environment, if you go back to it and you feel like this is what feels the most comfortable, the most Me than this is who you are. In a world like today where everywhere people are moving from one part of the world to another for a better life, you know, meeting people from other cultures and changing their lives with them, or whatever other reasons there's so many other reasons that people are - no - ethnic backgrounds are all mixing together and creating these amazing, amazing, amazing like inner cultures that all those definitions and labels are irrelevant compared to what do you feel you belong to.

An interesting finding was that two participant from Ukraine (Michael and Jeff), one from Latvia (Kate) and one from Belorussian (Melany) did not identify themselves with their country of birth and preferred "Russian" as one of the components of their identities. 


\section{How particular ethnic self-identity chosen, helped or complicated participants' integration into Canadian society?}

One of the secondary research questions was whether the identity developed by participants helped or complicated their integration into Canadian society. Each participant reported their opinion on this matter through interview process.

Only one participant stated that his Russian mixture in identity made it more difficult to integrate into Canadian society. Ironically, that was the only person who said that he feels Canadian:

It made it more difficult. You know, the people I chose to be with, they tend to be more Russian, and that kind of isolates you a little from Canadian society. Because, I don't live my life like a Canadian, like watch baseball and all that (Jeff, age 28).

All other seven participants stated that their identity helped them with their settlement process and did not make it difficult for them. Some of the better explanations are presented below:

I think that it helped me. Because in Canada you can actually see how... In Toronto they really like to promote your culturalism. It's very like, they give you a lot of security no matter which culture you have. And they want you to be proud of who you are. Understanding that we're all multicultural here and that and we all should be proud of who were are at the same time as we're proud to live in Canada and also proud to be Canadians (Melany, age 24).

I don't think so because I feel like we've always picked areas where there would be Russian people and Russian immigrants, just as much as we are. And when we would come to a country we would live in those areas and there would be just as many like other 
Russian immigrants who are the same as us and we would just make friends with them and we would feel like nothing really changed. You just speak a different language. I feel like that was a big part of it because since we were in our own area where there are so many people who are immigrants like Russian immigrants as much as we are that made it a lot easier and it didn't feel like, like most people feel when they come to a different country and there's a new language and no people to talk to. I feel that if that happened to us it would have been a lot harder for us (Paul, age 23).

Yeah, it's multicultural country and nobody cares if you're Jewish or Russian or whatever you are. I think in Israel, yeah, it was hard. Here no. Here whatever (Vivian, age 27).

I don't think it really mattered. It's like, when I came to Canada one of the things that I liked is everybody is doing what they want to do and at the same time being able to integrate as a society and a country while keeping part of themselves who they are from back home alive and kicking as I want to call it. So I don't think it impacted it really. If anything it made me realize that yes this is who I am (Rick, age 26).

They're so multicultural. You just stick with your group of friends, of people who are the same culture basically they are immigrants who immigrated to Russia and to Israel and then to Canada, that's most of us, like most of my friends are. Or if they're not, if they just immigrate just straight from Russia to Canada they're still Jewish and identify themselves as Jewish so easier, you know. But yeah, you just stick to yourselves and I guess to your own culture, to your own group (Kate, age 27). 
The overall conclusion was that their identity developed through two immigration experiences helped their settlement in Canada because this country celebrates cultures and allows citizens to be whoever they choose to be. My participants enjoy this freedom of choice and for some (such as Rick) it actually helped to understand who he is. Participants enjoyed the fact that they are not forced to integrate into mainstream society and can choose their environments based on their own criteria's. Considering the fact that all 8 participants are either studying in Canadian postsecondary education or already successfully participating in the Canadian labour force, I can make a conclusion that the fact that they chose to reside within their ethnic enclave did not affect their quality of life in Canada and also made their initial settlement process easier for them.

\section{Discussion}

Overall, my study findings were in line with the findings of the studies discussed in the literature review. Like the study by Birman, Persky and Chan (2010), my study found that majority of participants disclosed complex identities with two components. Just as in the other study, one of the participants was also struggling to explain her identity to people (Vivian, age 27). She disclosed that she calls herself Russian to make it easier for people rather than explaining that she feels Ukrainian-Jewish.

Birman, Persky and Chan (2010), also found that Jewish adolescent immigrants in USA were more associating themselves with American identity rather than identity related to FSU countries. My study did not support that finding. Although all participants had at least one parent with Jewish roots, there was no general connection found to a strictly Canadian identity for the majority of participants. Only one person called himself Canadian. In contrast as well, the study found that Jewish immigrant adolescents in USA had lower level of Russian identity connection than non-Jewish immigrant adolescents in USA (Birman, Persky, Chan, 2010). An important 
finding of my study showed that more than half (5 out of 8) of all participants declared that they have "Russian" as part of their ethnic identity, even in cases where the participant was from a different SFU country. My study supported Birman, Persky, Chan's (2010) finding that Jewish adolescent immigrants in USA had very low religious involvement. Not one of my participants focused on their religious affiliation and some specifically mentioned that they are not religious (Rick (age 26), Jeff (age 28) and Melany (age 24)).

The study by Sumetsky (2007) found that American child immigrants that arrived in the US before the age of 12 were more likely to connect themselves with identities related to FSU countries. All of my participants moved to Israel before age of 12 and the majority of participants did name identities related to their former countries, at least as part of their identity. As noted above, only one person, Jeff (age 28) identified as strictly Canadian.

Sumetsky (2007) predicted that age might play a role in the identity formation and adolescent decision to identify themselves with an FSU identity. Sumetsky's (2007) study did not support the importance of age during immigration in ethnic identity formation as well as my study. There was no clear relationship or connection established in my study, between age of immigration and identity formation. One of the participant, who moved to Israel at 9 months (Melany, age 24) still called herself Russian-Israeli. One person who moved to Israel the latest of all (Michael, age 30), also had Russian as part of his chosen identity. Paul (age 23) who migrated to Israel at age of 6 called himself Russian, while Rick (age 26) who moved there at the same age calls himself Israeli. More connection was found between numbers of years spent in Israel with ethnic identity formation: not surprising, those participants who spent the longest time in Israel, had "Israeli" as part of their identity (Melany (age 24), Vivian (age 27), Rick (age 26) and Kate (age 27)). 
Sumetsky (2007) also concluded that families played a significant role in ethnic identity formation of participants, especially among those whose parents put a lot of emphasis on cultural/language maintenance at home. My study also supported that fact. All participants were disclosing details about their family environment were parents were supporting their cultural and language maintenance, and took extra steps to make sure that their children are surrounded by Russian culture and language.

My study was also in-line with Remennick (2006), who did a study in Toronto of the Jewish immigrant community (a group that came straight from FSU countries, compared to those who re-migrated from Israel) and their identity and social integration. She found that both groups had mostly economic reasons to come to Canada, and that re-migrants had additional reasons such as cultural differences from Israelis, and safety and military service for their children. Through the interview process with my participants, I also found the same reasons connected to family decisions for their first and second migration.

My study also supported the finding by Remennick (2006) that Russian immigrants are trying to stay within their own communities and have little involvement in Canadian community life, although they feel welcomed and not discriminated against. All my participants reported very similar result. All appreciate Canada for providing them with opportunities to be who they want to be, however all of my participants chose to remain in more or less Russian speaking peer groups. Not one of my participants reported involvement in Jewish communities in Canada, which was in small contrast with Remennick's (2007) participant group. She found that remigrants from Israel with one parents who is non-Jewish, were trying to connect children to Jewish cultures to some extent (celebrations etc.). None of my participants reported that, although most of them had one Jewish and one non-Jewish parent. My study also supported the 
finding by Remennick (2007) that most of the children of those who she was interviewing said that they had Russian-speaking peer groups in Canada.

The study of special interest to me, by Glozman (2015) that was focusing on a similar topic and participant group also had similar results to my study but on a larger sample. Just like Glozman (2015), I found that my participants that went through two immigrations through Israel to Canada reported identity related to their parents place of birth (FSU countries). Only two reported "Israeli" and "Canadian" as their identity without connection to FSU countries, but one of them (Jeff, age 28) mentioned that he is Canadian with a little bit of Russian mixture in it. Glozman (2015) came to the overall conclusion that identity is a very fluid concept that can change according to situation and life experiences. I agree with that statement because my study supported that fact.

Glozman (2015) also found through her interviews that the "Jewish" part of a person's identity was more affiliated with culture rather than religion. That was also true for my study. Those who talked about their Jewish identity were talking about it from a cultural and not a religious standpoint, and specifically mentioned that they are not religious. Glozman (2015) also found that parents, peer groups and community (ethnic enclaves) are playing significant roles in ethnic identity formation. My study supported all these points through participant interviews. Everyone talked about their parents' strong influence, living in Israel and Canada surrounded by Russian-speaking immigrants, and having mostly Russian-speaking peer groups as being major influences on who they consider themselves to be, ethnically.

Remennick and Celnik (2011) who looked at FSU adolescents living in Israel supported the information that I got from my participants. One of the main findings of my study was that each and every one of my participants reported incidents of bullying at some point of their life in 
Israel (primarily in early school years) that made them choose Russian-speaking peer groups to associate with, which then also alienated them further from the mainstream culture. Those who stayed in Israel longer (Melany, Rick, Kate and Vivian) said that they had Israeli friends later in life, but also remembered the bullying in their early school years. Remennick and Celnik (2011) also found that their participants reported cases of abuse in school from their native classmates, which made them alienated and find safety within their own community. Just as these researchers, I strongly believe that negative experiences such as bullying based on culture/language/background is a strong factor in ethnic identity formation.

Other studies from the literature review also presented very similar results to what I found. For example, Shimmel and Wu (2015) found that first generation immigrants to Canada choose their original identity while their children tend to choose mixed identities. Most of my participants chose mixed identities which supports this finding. These authors' conclusion was that Canada's multicultural policy encourage immigrants to retain their identities and supports in in variety of ways. All my participants were very thankful for that fact and appreciated Canadian policy that gives them opportunity to be who they want to be. Another interesting finding of these authors was that discrimination based on background discourages immigrants from having a sense of belonging to a new country, and that is what I found about Israel from all my participant. I believe that the past negative experiences of my study participants contributed to them identifying more with their FSU identities (most of them), and immigration to Canada couldn't change that fact.

One more study that supported my research was by Trabka (2013). She found that role of parents and peers is very important in immigration experiences of their children. I found that parents and peers played an important role in the life of my participants and their adjustment to 
new countries. Most parents immigrated to make the life of their children better and was of great influence when it came to maintenance of culture at homes. Participants also talked about their Russian-speaking friends and people who were their "first" friends in Israeli and Canadian schools after immigration which made their transitional periods easier for them. Trabka (2013) found that most of her participants had fluid identities, and that social surroundings made them choose a specific identity to name. One of my participants also mentioned that struggle (Vivian, age 27).

My study findings also supported results gathered by Phinney, Romero, Nava and Huang (2000). These researchers found that parental cultural maintenance predicted adolescent first language proficiency. All my participants were fluent in Russian, their first language, despite the age of first immigration. Another result was that parents and peers of similar background play a very important role in ethnic self-identification of immigrant adolescents of various backgrounds. Almost all of my interviews supported that fact.

Lastly, I want to discuss the commonalities with a study done by Umana-Taylor, Bhanot and Shin (2006) that also found that ethnic identity formation was strongly influenced by families, across a variety of immigrants groups in the USA. In all groups, family appeared to be critical factor in identify formation. My study also supported that fact and I can conclude that family is one the main influences on ethnic identity formation along with peers groups and neighborhoods (ethnic enclaves) that immigrants are choosing to live in. To answers one of my secondary research questions, the factors that influence ethnic identity formation in adolescents are: family, peer groups and neighbourhood/ ethnic communities. 


\section{Implications for Theory}

My study results overall supported the theories that were chosen as a framework for my study. In this section, I created a hierarchy of theories chosen from the one that was most useful to explain results of the study, to less useful.

The theory that through analysis of results had the most impact on my research study was Urie Bronfenbrenner's Ecological Systems Theory. This theory states that a child's development is affected by his or her surroundings at various levels (Bronfenbrenner, 1977). Through the interview process and participants responses I could observe how they were affected by different layers of the Ecological System. From the microsystem perspective, family and peers played a very important role in their everyday life. Decisions made by parents impacted every participant and affected different aspects of their being as well as how they think of themselves. Their peer groups and school experiences also shaped and affected their life and as a result, their identity formation. From the mesosystem perspective which is a linkages between the immediate layers of environments (for example school and parents) also could be traced in some of the responses of my participants. For example Rick (age 26) talked about the decision of his parents to put him in a Russian school in Israel to maintain his "Russian" education. Melany (age 24) also talked about religious school that her parents put her in in the beginning and how they took her out when she had negative experience with it. Michael (age 30) also talked about teacher's initiative to ask another Russian speaking boy in Canadian school to be friends with him and show around to make it easier for him to settle down in the new environment. All these examples show linkages between the immediate surroundings (mesosystem) and how it affected my participants' experiences and development of their identity. From the exosystems perspective which is the layer that indirectly affects child (parents' workplace for example), some of my participants were 
talking about parents' experiences through immigration. These experiences included difficulties to find work, depression, difficulty to understand Israeli culture, their choice of neighborhoods to live etc. All these experiences impacted my participants indirectly by affecting their lifestyle, places they ended up living, choice of school sand many other things in their life that in the end also affected their identity they chose to name. Many of them were talking about their parents' decisions, consciously mentioning that it did affect them after all. On the macrosystems level, which are the cultural/social surrounding child lives in, my participants were definitely affected and it could be seen through their responses. They all talked about the cultural differences in Israel which led to a traced pattern of negative experiences of my participants (bullying incidents). Some also talked that they were feeling almost forced into the mainstream society in Israel and it made them uncomfortable and impacted their choices almost unconsciously. When remembering all these events, participants made connections to their identity formation that was definitely impacted by social/cultural surroundings in FSU countries, Israel and Canada. Lastly, the chronosystem layer of the theory which looks at the historical conditions that child develops in also could be connected to how my participants grew and developed. The fall of Soviet Union, Jewish immigration waves to Israel, the constant war between Israel and surrounding countries and finally Canadian multicultural policy all had an impact on life of my participants and their families and led to specific circumstances, decisions and similar reason for immigration.

The second theory that I used had more of bigger perspective on the process of ethnic identity formation through intra-interpsychologycal processes. I theorized that positive and negative experiences shape and impact identity formation. This social constructivist approach that was theorized by Lev Vygotsky in 1930 represented my study findings. Through social interactions with friends, family, and school environments (teachers, peers in Israel and Canada, 
negative incidents, like bullying, that happened with native Israeli groups), their cultural development happened on an interpsychological level and later transformed through intrapsychological level to the identity they have today. Participants were absorbing these experiences through interactions with people (as a learning process), internalizing and building concepts about their identity.

The two last theories that I chose had stage format, and after doing my research study and speaking to participants, I support the idea that identity is fluid and can still change for all my participants. I do agree with Phinney's Ethnic Identity Development Theory who explained the process of unfolding of identity formation really well (the age when it starts and the social processes), and Erickson theorization of identity development as one of the main achievements of adolescence, but I want to critique both theorists for having a "fixed" result in their theories. I think that ethnic identity doesn't have a final result. According to my research results, ethnic identity is fluid and changes with experiences that person has through life. Despite the disagreement, I will explain how I used these theories in connection to my research results:

Phinney's Theory of Ethnic Identity Formation (1996). During the first stage called Unexamined Ethnic Identity, my participants were not thinking about who they are and just accepted whatever was given to them by parents/ other environments such as school and peers. They weren't making conscious decisions about why they choose peer groups of Russianspeaking children, were speaking Russian at home because parents were telling them to and were just going with the flow. On the second stage of the theory called Moratorium or Exploration Stage, my participants were starting to think about who they are. According to Phinney (1996) ethnic identity at this stage is very ethnocentric and positive towards their own ethnic group, the one they feel most comfortable connecting with. My participants were talking about choosing 
Russian-speaking groups in their mid-teen years (in Israel and in Canada) because that felt the most comfortable for them to do and helped them to settle down and not feel alienated. At the third stage which is the Achieved Ethnic Identity, all my participants chose a specific identity that was the result of the combination of their positive and negative experiences. Some of them (such as Rick and Jeff) chose identities as Israeli and Canadian while some stayed Russian (Paul) or developed a mixed identity (John, Michael, Melany, Vivian, Kate) connected to their countries of origin and either other country of living or culture (Jewish).

The last theory that was the least useful for my research was Erik Erickson's Identity Formation (1968). The main idea is that identity develops in adolescence and is one of the main developmental achievements of this age. All of my participants do not remember how they were thinking about themselves in FSU countries. Their memories about the time when they "decided" on their ethnic identity all falls on their teenager and later years (around 20s), mostly at the time of their second immigration and settlement in Canada. For some who left Israel later (Rick and Kate), they already "chose" identities when they came to Canada in later teen years. Despite the "chosen" identities, some of them were bringing up their thought about their identities that might change in the future after living in Canada for many years, or moving to another place and having new and different experiences.

Overall my research found supports the theories I chose in this study. 


\section{Policy recommendations}

This study and findings can be used to help construct a series of policy recommendations. First and foremost, my study found that negative experiences in school environment such as bullying based on cultural/ethnic differences can potentially cause alienation from the mainstream society and push children towards other ethnic groups, where they feel more comfortable. They stay together for the reasons of safety and shared background. According to the findings of my study, this seems especially relevant in the primary school years as some of my participants who stayed in Israel for middle and high school years disclosed that they did make friends with native Israelis and that the peer groups became more mixed as they grew up. While my participants did not feel that Canada has similar problems and their transition to Canadian schools was smooth (and I did not have information about primary grades in Canada because all of them came later in life), their experiences reminds us that elementary school teachers should do what they can to support immigrant children's integration and minimize negative interactions with local children.

Further research is required to find out the relationship between ethnic groups in middle and high schools in Canada. My participants disclosed that in Canada they continue to stay primarily within their ethnic groups, which might contribute to discrimination and negative behaviour between and across different ethnic groups. It might be especially dangerous for groups from countries that have political disagreements (such as Israel and some Muslim countries). Further research is needed on it to create policy recommendations for teaching staff, social and settlement workers. 


\section{Ethnic peer groups in schools}

The formation of ethnic peer groups in schools calls for more research on the settlement process. My study findings did not demonstrate that participants experienced challenges with integration into Canadian society. They were quite successful through high school and postsecondary, and most of them have already entered the Canadian labour market in variety of professional occupations. However, the study by Remennick (2006) mentioned that some of the children of Russian-speaking immigrants were having problems with settlement in Canada because of their choice to stay within ethnic enclave. Further research is needed to understand the reasons for that matter in order to support these children in the settlement process.

\section{Roles of families}

The importance of family in the life of adolescents, especially in transition periods of immigration, was traced through my study as one of the most important findings. I think that the Canadian school system should not underestimate the role of parents and involve them as much as possible to help children with the process of integration. Communication between parents/caregivers of newcomer children and their teachers should be one of the priorities for Canadian school system in order to support them in the best way through their transition to a new environment. Settlement workers and translators should be available for service in neighbourhoods with high percentage of newcomer children. 


\section{Implications for other groups of immigrant youth}

Although my research was focused on a specific ethnic group with very specific immigration pathway, I think that it can be used as a platform for research and policy implications for other groups of immigrant adolescents in Canada. According to the literature and the findings of my research, factors that influence the identity formation for different youth immigrant groups are: peers, family, and living in ethnic enclaves (or immigrant communities). Based on these findings, I can make an assumption that those factors might have an impact on ethnic identification of other groups of immigrant youth. Similar research is needed with other ethnic communities to support this assumption.

The study by Shimmel and $\mathrm{Wu}(2015)$ as well as my study shows that 1.5 generation immigrants (those who immigrate with their parents) in many cases develop mixed identities. My study proved that fact by resulting in majority of participants claiming mixed identities. Shimmel and $\mathrm{Wu}$ (2015), who had a sample of immigrants from different countries, found similar results - mixed identities for most of 1.5 generation of immigrants to Canada.

Lastly, I wish to discuss the importance of understanding the negative impact of bullying based on background--one of my main findings of my study. As I found, this created consequences for my participants resulting in them forming their relationship mostly with Russian-speaking groups. I suggest that this is studied further to assess the impact on other immigrant groups and on identity function. 


\section{Conclusion}

Overall, I found that most participants have mixed identities. Family, friends, negative experiences in school and living in ethnic enclave communities are the factors that influence development of ethnic self-identity of adolescents the most. The ethnic identity chosen by participants did not seem to complicate their settlement process into Canadian society.

That said, there were some limitations to this research study that lead to limited amount of data gathered. First and foremost, my small sample size could only provide results for 8 participants. It is too small to represent the population of Russian-speaking Israeli Canadian people who went through two-step immigration.

Furthermore, recruiting through Facebook community groups in Toronto limited the sample to participants living in GTA area. Snowball sampling also narrowed results because people were referring others that went through similar pathway meaning they are also from similar newcomer area.

Another limitation is that I wasn't able to gather the planned 10 participants to make a comparison study between female and male immigrants to see how their experiences may differ.

Lastly, my study was limited by the short time available for data gathering, analysis and writing. Having more time to recruit more participants would result in more interviews, and no doubt would result in richer analysis and findings.

Future research (at the PhD level, perhaps) is needed with considerations of all limitations mentioned above in order to fill some of the gaps and expand on my study. Even having a limited scope, my study presents valuable results that can be used for future research and published as well. My findings can also be used as a comparison study for similar studies. My 
study can be expanded into $\mathrm{PhD}$ research with more participants involved from other regions of Canada. It also provided important qualitative results about ethnic identity formation of immigrant adolescents that went through two step immigration through Israel to Canada from FSU countries with real experiences and details of life of each participant. The format of the interviews allowed me to gather very valuable insights into the story of multiple migrations of each participant and allowed to draw conclusions about similarities across stories.

My study might be useful for community organizations working with this immigrant group and to scholars who research ethnic-identity development under an influence of multiple immigrations and other immigrant adolescent groups. My research also presented the unique circumstances of this particular immigrant group from FSU countries with experience of living in Israel. 


\section{Appendix A: Letter of Information}

\section{Letter of Information}

I'm a graduate student researcher Natalia Markman, completing my Master's program in Immigration and Settlement Studies. I am conducting a small-scale research study under the supervision of Professor Patrizia Albanese, PhD. The following information is provided for you to decide whether you wish to participate in a study trying to understand how multiple immigration experiences in childhood may influence individual's ethnic self-identification. I will specifically focus on immigrants born in Former Soviet Union countries that immigrated to Israel in childhood/teen years and then to Canada before the age of 18 .

Your participation in the study will involve one face-to-face interview and will include questions regarding your ethnic self-identification and immigrant experiences. This interview should take only about 30 minutes of your time and will be conducted in a public setting such as a public library that is most convenient for you.

Participation in the research study is voluntary and you may refuse to participate in this study without explanation or penalty. You may refuse to answer any of the questions during interview if you feel uncomfortable and don't want to share specific experiences. Also, you may choose to withdraw your participation at any time after the study has been completed by sending me a request to withdraw by email. Upon your request to withdraw from the study, all information related to you including interview transcript, signed consent letter, notes and audio-recording will be erased/shredded within 24 hours.

Your identity will be treated as confidential information. Your name will be removed from all documents and replaced with number code such as: Participant 1 . The list of names with numerical codes will be kept in a secured file. The paper copies of the data collected from this study will be kept in a locked cabinet and the transcripts of the data will be kept in password protected computer files, where they will be accessible exclusively by me. The raw data collected will be permanently destroyed after three years following completion of the study. The findings of the study based on the interviews with participants will be viewed by my research supervisor, Patrizia Albenese and will be presented during the defence of my Major Research Paper, may be discussed scholar settings such as conference or community organization, and may be published, but will not include any identifiable information about you.

There are minimal risks associated with your participation in this study (you may feel uncomfortable talking about your experiences; but you can skip any questions). There is no compensation for participating in my research study. This study has the potential to benefit community organizations in Toronto who work with immigrants from this particular group or scholars who research similar topics.

The findings of the research will be made available to you electronically after September 2016, following the defence of my research study. You will be contacted by me and provided with a link to my completed Major Research Paper.

If you have any questions about this study or about your participation in it, please feel free to contact me via email addresses listed below. You may now choose to provide your consent to participate in this study by signing the attached consent form.

Thank you for your interest in my study as your input is very valuable!

\section{Sincerely,}

Natalia Markman nmarkman@ryerson.ca 


\section{Appendix B: Consent Form}

\section{Consent Agreement}

You are being invited to participate in a research study. Please read this consent form so that you understand what your participation will involve. Before you consent to participate, please ask any questions to be sure you understand what your participation will involve.

RESEARCH STUDY TITLE: “Impact of multiple immigration experiences in childhood on ethnic self-identity: Case study of Russian-speaking Israeli-Canadians"

INVESTIGATORS: This study is being conducted by Natalia Markman, as part of her Master's Major Research Paper in the Immigration and Settlement Studies Program, under the supervision of Dr. Patrizia Albanese from the Department of Sociology at Ryerson University. If you have any questions or concerns about the research, please feel free to contact:

\section{Natalia Markman}

\section{nmarkman@ ryerson.ca}

\section{PURPOSE OF THE STUDY:}

The purpose of this study is to explore how multiple immigration experiences in childhood may influenced your feeling of belonging to a specific ethnic group. It will focus on immigrants born in Former Soviet Union countries (such as Russian Federation, Belorussia, Ukraine, Latvia, Kazakhstan and others), that immigrated to Israel in childhood/teen years and then to Canada before the age of 18. I will be conducting 30-minute one-on-one interviews with approximately ten participants, asking questions about your ethnic identity and your childhood experiences related to life in the Former Soviet Union country, your life in Israel and then in Canada. The results of this study will contribute to my Major Research Paper required for the graduation from MA program in Immigration and Settlement Studies.

\section{WHAT YOU WILL BE ASKED TO DO:}

If you volunteer to participate in this study, you will be asked to do the following things:

1. Review and sign this consent form.

2. Participate in a 30 minute face-to-face interview in the public library closest to you. During the interview you will be asked questions about:

- Your personal feeling of attachment to a specific ethnic group (for example Russian, or Israeli, Canadian, Jewish Canadian, Ukrainian, Belorussian etc.) 
- Your immigrant experiences in Former Soviet Union country, in Israel and in Canada

- Other questions will be related to your family traditions, role of religion for you, language you speak at home and with friends etc.

- Interview will be audio-recorder, if you agree, and the researcher will take notes

\section{POTENTIAL BENEFITS:}

This study has the potential to benefit community organizations in Toronto who work with immigrants from this particular group or scholars who research similar topics. I cannot guarantee, however, that you personally will receive any benefits from participating in this study.

\section{WHAT ARE THE POTENTIAL RISKS TO YOU AS A PARTICIPANT:}

This study involves a very low potential risk to you as a participant. During the interview you will be asked some questions about your past experiences and feelings related to your personal experiences. You may feel uncomfortable answering some of the questions during interview that might bring up unpleasant memories that you don't wish to talk about. In such cases, know that you can skip any questions that you do not want to answer, inform the researcher about your discomfort, or stop the interview at any time.

\section{CONFIDENTIALITY:}

Your identity will be treated as confidential. Your name will be removed from all documents and replaced with number code such as: Participant 1 . The list of names with numerical codes will be kept in a secured file in the researcher's home office. The paper copies of the data collected from this study will be kept in a locked cabinet and the transcripts of the data will be kept in password-protected computer files, where they will only be accessible to the researcher. If you wish to review or edit the transcript of your interview you have the right to do so. The raw data collected will be permanently destroyed after three years following completion of the study. The findings of the study based on the interviews with participants will be viewed by my research supervisor, Dr. Patrizia Albanese and will be presented during the presentation of my Major Research Paper, may be discussed scholarly settings such as conference or community organization, and may be published, but will not include any identifiable information about you.

INCENTIVES FOR PARTICIPATION: You will not be paid to participate in this study.

COSTS TO PARTICIPATION: There are no costs for participation in this research study.

\section{VOLUNTARY PARTICIPATION AND WITHDRAWAL:}

Participation in this study is voluntary and you may stop participating in this study at any time without explanation or penalty. If any question during the interview makes you uncomfortable, 
you can skip that question. If you choose to stop participating, you may also choose to not have your data included in the study. If you choose to withdraw from the study you should notify the researcher before July 20, 2016 by sending an email request to the researcher. Upon your request to withdraw from the study, all information related to you including interview transcript, notes and audio-recording will be erased/shredded within 24 hours. Your choice of whether or not to participate will not influence your future relations with Ryerson University or the investigator Natalia Markman involved in the research.

QUESTIONS ABOUT THE STUDY: If you have any questions about this research study you can contact:

\author{
Natalia Markman \\ Dr. Patrizia Albanese \\ Research Investigator \\ Research Supervisor \\ nmarkman@ ryerson.ca \\ Ryerson University \\ 350 Victoria Street \\ Toronto, ON M5B 2K3 \\ 416-979-5000 ext 6526 \\ palbanes@soc.ryerson.ca
}

This study has been reviewed by the Ryerson University Research Ethics Board. If you have questions regarding your rights as a participant in this study please contact:

\author{
Research Ethics Board \\ c/o Office of the Vice President, Research and Innovation \\ Ryerson University
}

350 Victoria Street

Toronto, ON M5B 2K3

416-979-5042 


\section{CONFIRMATION OF AGREEMENT:}

Your signature below indicates that you have read the information in this agreement and have had a chance to ask any questions you have about the study. Your signature also indicates that you agree to participate in the study and have been told that you can change your mind and withdraw your consent to participate at any time. You have been given a copy of this agreement. You have been told that by signing this consent agreement you are not giving up any of your legal rights.

Name of Participant (please print)

Signature of Participant

Date

I agree to be audio recorded for the purposes of this study. I understand how these recordings will be securely stored and destroyed after 3 years or immediately, in case of your withdrawal. 


\section{Appendix C: Semi-Structured Interview Guide}

1. Where were you born?

2. Do you have any memories of your life there?

3. What is the background of your parents?

4. How old were you when your family moved to Israel?

5. Do you know what made them decide to move to Israel?

6. How long were you in Israel?

7. Did you go to school in Israel?

8. Did you live in an immigrant neighborhood in Israel?

9. What was life like in Israel?

10. When did you family move to Canada?

11. Do you know what made them decide to move to Canada? Why they didn't want to stay there?

12. How old were you when you came to Canada?

13. Immigration is usually a major life event when it happens once, do you think that a double migration made it easier or harder for you? Why?

14. How do you identify yourself in terms of your ethnicity? By ethnicity I mean your sense of attachment to a specific culture or ethnic group.

15. Did that change with each migration? Why do you think so/not?

16. What did you consider yourself when you were in Former Soviet country? (If you were old enough to remember) When in Israel? Now in Canada? 
17. What were the main factors that you think have contributed to this specific identity that you named? Tell me about some experiences that you think contributed to the way you think about yourself now.

18. How this particular ethnic self-identity helped or complicated your settlement in Israel and in Canada?

19. What is the language you speak at home now?

20. What is the background of your closest friends?

21. Would you prefer your children to share the same values/traditions/language/religion as yours or you would prefer them to be fully assimilated into Canadian society? If yes to the first question, how would you make sure they learn about your values/traditions/culture? 


\section{Appendix D: Recruitment post for Facebook community groups}

My name is Natalia Markman, and I'm MA student in Immigration and Settlement Studies at Ryerson University doing a study on the topic: "Impact of multiple immigration experiences in childhood on ethnic self-identity: Case study of Russian-speaking Israeli-Canadians”.

If you were born in any Former Soviet Union countries (such as Russian Federation, Belorussia, Ukraine, Latvia, Kazakhstan and others), and had an immigrant experience living in Israel in your childhood/teen years and came to Canada before the age of 18 , you are a great candidate for this research study. I will be conducting 30-minute interviews asking questions related to your ethnic self-identification and your childhood experiences related to life in Former Soviet Union country and your life in Israel and Canada. If you're interested in participating in this study please contact me via email: nmarkman@ ryerson.ca. Your input is very valuable as it will help to add to the body of literature related to ethnic-identity development in childhood as well as to the understanding of unique experiences of this particular immigrant group. Please respond through email or private message me. DO NOT RESPOND directly to this post. 


\section{Appendix E: Research Ethnics Board Approval}

REB 2016-157

Project Title: Impact of multiple immigration experiences in childhood on ethnic self-identity: Case study of Russian-speaking Israeli-Canadians

Dear Natalia Markman,

The Research Ethics Board has completed the review of your submission. Your research project is now approved for a one year period as of May 19, 2016.The approval letter is attached in Adobe Acrobat (PDF) format.

Congratulations and best of luck with the project.

Please note that this approval is for one year only and will expire on May 19, 2017. Shortly before the expiry date a request to complete an annual report will be automatically sent to you. Completion of the annual report takes only a few minutes, enables the collection of information required by federal guidelines and when processed will allow the protocol to remain active for another year.

Please note that REB approval policies require that you adhere strictly to the protocol as last reviewed by the REB. Any modifications must be approved by the Board before they are implemented. Adverse or unexpected events must be reported to the REB as soon as possible with an indication from the Principal Investigator as to how, in the view of the Principal Investigator, these events affect the continuation of the protocol.

Please quote your REB file number (REB 2016-157) on future correspondence.

If you have any questions regarding your submission or the review process, please do not hesitate to get in touch with the Research Ethics Board (contact information below).

No research involving humans shall begin without the prior approval of the Research Ethics Board.

This is part of the permanent record respecting or associated with a research ethics application submitted to Ryerson University.

NOTE: This email account (rebchair@ryerson.ca) is monitored by multiple individuals. If you wish to contact a specific member of the Research Ethics Board, please do so directly.

Yours sincerely,

Toni Fletcher, MA

Research Ethics Co-Ordinator on behalf of

Lynn Lavallée, Ph.D.

Chair, Ryerson University Research Ethics Board 
(416)979-5000 ext. 4791

lavallee@ryerson.ca

rebchair@ryerson.ca

http://www.ryerson.ca/research

Toni Fletcher, MA

Research Ethics Co-Ordinator

(416)979-5000 ext. 7112

toni.fletcher@ryerson.ca

Zakiya Atcha, MSW

Research Ethics Co-Ordinator

(416)979-5000 ext. 4841

zakiya.atcha@ryerson.ca 


\section{References}

Ali, Mehrunnisa, with Sviltana Taraban and Jagjeet Kaur Gill. 2003. 'Unaccompanied/Separated Children Seeking Refugee Status in Ontario: A Review of Documented Policies and Practices'. Toronto: Joint Centres of Excellence for Research on Immigration and Settlement, CERIS Working Paper No. 27.

Birman, D., Persky, I., \& Wing Yi, C. (2010). Multiple identities of Jewish immigrant adolescents from the former Soviet Union: An exploration of salience and impact of ethnic identity. International Journal Of Behavioral Development, 34(3), 193-205. doi: $10.1177 / 0165025409350948$

Bronfenbrenner, U. (1994). Ecological models of human development. In International Encyclopedia of Education, Vol 3, $2^{\text {nd }}$. Ed. Oxford. Elsevier. Reprinted in: Gauvain, M. \& Cole, M. (Eds), Reading on the development of children, $2^{\text {nd }}$ Ed. (1933, pp. 37-43). NY: Freeman

Bronfenbrenner, U. (1977). Toward an experimental ecology of human development. American Psychologist, 32(7), 513-531. doi:10.1037/0003-066X.32.7.513

Cresswell, W., J. (2014). Research design: Qualitative, quantitative and mixed methods approaches. Thousand Oaks, US: SAGE Publications.

Erickson, E. (1968). Youth, Identity and Crisis. Norton \& Company Inc. New York

Glozman, J. (2015). Being me in Canada: Multidimensional identity and belonging of Russianspeaking immigrant youth (Doctoral dissertation, University of Guelph). Retrieved from 
http://atrium.lib.uoguelph.ca:8080/xmlui/bitstream/handle/10214/9256/Glozman_Jenny_20 1509_PhD.pdf?sequence=1\&isAllowed=y

Harper, R. A., Zubida, H., Lavi, L., Nakash, O., \& Shoshani, A. (2013). Home and away: Hybrid perspective on identity formation in 1.5 and second generation adolescent immigrants in israel. Glocalism: Journal of Culture, 2013(1) doi:10.12893/gjcpi.2013.1.6

Kappeler, A. (2014). Ukraine and Russia: Legacies of the imperial past and competing memories. Journal of Eurasian Studies, 5(2), 107-115. doi:10.1016/j.euras.2014.05.005

Phinney, J. S., Romero, I., Nava, M., \& Huang, D. (2001). The role of language, parents, and peers in ethnic identity among adolescents in immigrant families. Journal of Youth \& Adolescence, 30(2), 135.

Phinney, J. S. (1996). Understanding ethnic diversity: The role of ethnic identity. American Behavioral Scientist, 40(2), 143-152. doi:10.1177/0002764296040002005

Remennick, L., \& Celnik, P. (2011). The children of 'Russian' immigrant parents in Israel: Identity and social integration. Sociological Papers, 16, 1.

Schimmele, C. \& Zheng W. (2015). The New Immigration and Ethnic Identity. Population Change and Lifecourse Strategic Knowledge Cluster Discussion Paper Series/ Un Réseau stratégique de connaissances Changements de population et parcours de vie Document de travail: Vol. 3: Iss. 1, Article 1. Retrieved from Google Scholar database

Statistics Canada. (2011). Immigrant languages in Canada. Ottawa, ON: Author. Retrieved from http://www12.statcan.gc.ca/census-recensement/2011/as-sa/98-314-x/98-314-x2011003_2eng.pdf 
Statistics Canada. (2006). Population by selected ethnic origins, by province and territory (2006 Census). Ottawa, ON: Author. Retrieved from http://www.statcan.gc.ca/tablestableaux/sum-som/101/cst01/demo26a-eng.htm

Remennick, L. (2006). Russian Jews in the global city of Toronto: A pilot study of identity and social integration. Espace populations sociétés, 2006, no 1, p. 61-81. Retrieved from https://eps.revues.org/1235\#text

Sumetsky, N. (2007). Layers of identity: Self-identity in U.S child immigrants from the former Soviet Union (Master's Thesis, University of Pittsburg). Retrieved from http://www.sras.org/self-identity_in_us_child_immigrants_from_the_fsu

Trabka, A. (2013). "On the road again"- Identities of third culture kids. Being chameleon: The influence of multiple migration in childhood on identity construction (based on $\mathrm{PhD}$ dissertation, Pontifical University of John Paul II, Krakow). Retrieved from Google Scholar database.

Vygotsky, L. (1978). Interaction between learning and development. From: Mind and Society. (p. 79-91). Cambridge, MA: Harvard University Press. Reprinted in Reading on the Development of Children, $2^{\text {nd }}$ Ed. Gauvain, M. \& Cole, M. (Ed.). (1997). W. H. Freeman and Company: New York

Umaña-Taylor, A. J., Bhanot, R., \& Shin, N. (2006). Ethnic identity formation during adolescence: The critical role of families. Journal of Family Issues, 27(3), 390-414. doi: $10.1177 / 0192513 X 05282960$ 


\section{Glossary:}

Ethnic self-identity: "Ethnic identity refers to an individual's sense of self in terms of membership in their native culture or ethnic group. It is contrasted with national identity that refers to the extent of identification with the country wherein the immigrants now reside" (Birman et al., 2010, p. 194)

Immigrants from Former Soviet Union Countries (FSU): Immigrants who were born in any countries that were formerly a part of Soviet Union and now are independent states such as Russian Federation, Ukraine, Belorussia, Kazakhstan, Latvia etc.

Multiple immigration experience or two-step immigration: These terms are used to explain the experiences of people who were born in one country, and immigrated twice or more to the final destination or current place of residence. In this paper this term is used to primarily define people born in FSU countries that immigrated to Israel and then to Canada as their next destination.

Immigrant or immigration experience: This is a term that compounds all factors related to immigration. Experiences can be negative or positive (or both) and include different aspects of immigration process such as language learning, settling in a new environment/community, making friends, attending school, experiencing cultural differences etc.

Hybrid Ethnic Identity: This term will be used to describe the fluid, dynamic and flexible identity of immigrant adolescence that can include multiple self-labels and shifts in identity (Harper, Zubida, Lavi, Nakash, \& Shoshani, 2013). 